\title{
The Processing of Non-Timber Forest Products through Small and Medium Enterprises-A Review of Enabling and Constraining Factors
}

\author{
Kathrin Meinhold *(D) and Dietrich Darr ${ }^{(D)}$ \\ Faculty of Life Sciences, Rhine-Waal University of Applied Sciences, Marie-Curie-Straße 1, \\ 47533 Kleve, Germany; dietrich.darr@hochschule-rhein-waal.de \\ * Correspondence: kathrin.meinhold@hochschule-rhein-waal.de; Tel.: +49-2821-80673-9731
}

Received: 20 October 2019; Accepted: 12 November 2019; Published: 14 November 2019

\begin{abstract}
Research Highlights: This study reviews the available literature on processed non-timber forest products (NTFPs) in order to comprehensively identify relevant factors enabling or constraining their potential to contribute to rural development. Background and Objectives: NTFPs, such as wild foods, medicinal plants, and raw materials for handicrafts, make significant contributions to rural livelihoods. NTFPs can help fulfil households' subsistence and consumption needs, serve as a safety-net in times of crises, and provide cash income. In particular, the processing of NTFPs has often been suggested to positively influence sustainable economic development in rural areas. However, despite rising interest and recognition of the potential contributions of such industries as key sources of employment and their strategic role in overall growth strategies of developing countries, many NTFP processing enterprises remain in the informal sector and an in-depth understanding of the underlying factors is lacking. This review aims to identify enabling and constraining factors affecting NTFP processing enterprises. Materials and Methods: Using systematic review methodology, studies investigating commercialized, processed NTFPs and their economic impacts have been identified and the current evidence base with regard to NTFP processing and small and medium sized enterprise (SME) development synthesized. Results: Despite the diverse nature of NTFPs, a number of constraining and enabling factors affecting NTFP processing and commercialization were identified. The former includes aspects such as the lack of resource access (finances, skills, technologies, etc.), market information, and basic infrastructure; the latter, amongst others, the role of key entrepreneurs; and cooperation across the value chain, amongst producers, and among members of the institutional environment or an abundant resource base. Moving from small-scale NTFP commercialization in local markets to more mature NTFP value chains reaching export markets, the increasing role of cooperation and having a supportive institutional framework in place, becomes apparent. Conclusions: Overall, successful NTFP processing strongly depends on the socio-economic and environmental context in question, requiring a holistic approach tailored to the respective context and value chain.
\end{abstract}

Keywords: NTFP; commercialization; processing; SME

\section{Introduction}

The role of non-timber forest products (NTFPs), including wild foods, forage, medicinal plants, construction materials, fuelwood, and raw materials for handicrafts is increasingly being recognized. Many studies have demonstrated the important contribution of NTFPs to fulfilling households' subsistence and consumption needs [1-14]. Evidence suggests that poorer households are often more dependent or derive greater benefits from NTFPs for their livelihoods [5,15-18]. NTFPs can also serve 
food security objectives by contributing to diet diversification, providing micronutrients [19-21], and providing safety-nets in times of crises [12,22-27]. However, fluctuations in NTFP availability may limit this buffer function [28,29]. Provisions of cash income and subsequent entry into the cash economy are further benefits of NTFPs [30,31], although income contribution may strongly vary depending on ecological and socioeconomic settings [32]. The often-overlooked contribution of NTFPs to national economies can be substantial [33-35].

Against this background, the commercialization of NTFPs, which can occur via selling raw or processed resources, has often been promoted, since it can potentially fulfil both conservation and development objectives and lead to livelihood diversification [36]. Commercialization of NTFPs has been demonstrated to be financially competitive in comparison to crop production [37]. However, the conservation-through-use approach often does not hold in practice [38-41]. Common problems include environmental implications, such as overexploitation or alteration of the resource and encompassing ecosystems [36,42]. Benefits to local livelihoods have also been questioned [36,43]. However, often no distinction is made between different commercialization strategies. The value addition of NTFP resources via processing and enterprise development deserves particular attention, since it may have more potential to contribute to employment opportunities and income generation [21,44-51]. Despite widespread use for subsistence, more professional NTFP commercialization is often still in its infancy, particularly in the global south $[21,52,53]$. However, the processing of NTFPs, and the subsequent enterprise development, is one of few options rural economies have $[43,52]$. The benefits of processing NTFPs are potentially significant in terms of improved livelihoods for these communities [53]. With increasing processing and commercialization of NTFPs, however, the question remains, at which stage these can still be classified as NTFPs. It is currently disputed whether products collected at industrial scale can still be associated with the NTFP category [54]. Through cultivation and domestication, NTFPs can start to enter agricultural value chains [55].

Against this background, this review aims to identify enabling and constraining factors affecting pro-poor NTFP commercialization and the development of small and medium sized enterprises (SMEs) based on processing the resources. Using systematic review methodology, studies investigating processed, commercialized NTFPs and their economic impacts have been identified and categorized depending on their levels of commercialization. Naturally, upgrading opportunities do not prevail for all NTFPs but often concentrate on selected species, serving niche or export markets. Nevertheless, such markets may still be substantial and benefit many [43].

Previously conducted reviews have not approached NTFP processing in depth, but focused on the ecological implications of NTFP harvesting (e.g., [56-61]), the safety net function of NTFPs (e.g., [12,62]), or their role in nutrition security (e.g., $[19,63])$. Others have critically reflected on the question of whether forest conservation can occur through the commercialization of NTFPs $[36,38,39,64,65]$. Several reviews have investigated the contributions of NTFPs, and more generally, of forest or environmental incomes on livelihoods and poverty alleviation (e.g., [1,14,66-74]). However, these typically do not specifically focus on commercialized NTFPs. Reviews which do focus on the role of commercialized NTFPs in livelihoods $[75,76]$, do not specifically address processing activities.

\section{Materials and Methods}

In order to consolidate the current evidence base on processed, commercialized NTFPs, the systematic review approach, as illustrated by Petticrew and Roberts 2012, was applied. It provides clear procedures, starting from refining the research question, moving on to retrieving the literature, and finishing with synthetizing the evidence [77]. Keywords for the literature search were divided into two categories, the first of which considered NTFPs and synonyms such as "non-wood forest product," "NWFP," or "edible wild plants." The second category reflected keywords associated with commercialization and processing, such as "product develop*," "market"," "upgrad"," "process*," "enterprise," or "SME." The combination of the keywords of both categories using the Boolean operator "and" across five different scientific search engines (Web of Science, Science direct, T\&F online, and 
Emerald, Springer online) led to the identification of 16,951articles. Studies were included in the final database based on the adoption of exclusion and inclusion criteria defined in Table 1. The selection process was conducted in three steps, first via screening the titles, secondly the abstracts, and finally, by screening the specific content of the full-text articles against the inclusion and exclusion criteria. In addition to the keyword-search, citation searching in full-text articles was conducted to identify further candidate studies. Overall, the literature search and application of the inclusion and exclusion criteria resulted in the identification of 83 studies focusing on commercialized, processed NTFPs (Figure 1). The literature search was conducted early 2019 and repeated in July 2019 to cover for newly published articles. It is anticipated that the database comprehensively captures the rapidly expanding literature on NTFP processing. Nevertheless, it cannot be ruled out that a small number of relevant studies have been excluded.

Table 1. Eligibility criteria.

\begin{tabular}{lll}
\hline \multicolumn{1}{c}{ Criteria } & Inclusion & Exclusion \\
\hline Publication type & $\begin{array}{l}\text { Selection of peer-reviewed academic } \\
\text { journals in English from all times }\end{array}$ & $\begin{array}{l}\text { Exclusion of books, book chapters, } \\
\text { reports, conference proceedings, } \\
\text { or dissertations }\end{array}$ \\
\hline Study design & $\begin{array}{l}\text { Inclusion of both quantitative and } \\
\text { qualitative empirical studies }\end{array}$ & $\begin{array}{l}\text { Exclusion of studies assessing } \\
\text { potential of a NTFP theoretically }\end{array}$ \\
\hline NTFP & Selection of NTFPs across all regions & $\begin{array}{l}\text { Exclusion of animal products, } \\
\text { illegal activities and tourism }\end{array}$ \\
\hline Commercialization & Inclusion of studies focusing on & $\begin{array}{l}\text { Exclusion of studies with main } \\
\text { research focus on subsistence use } \\
\text { and sole marketing of raw NTFPs }\end{array}$ \\
\hline
\end{tabular}

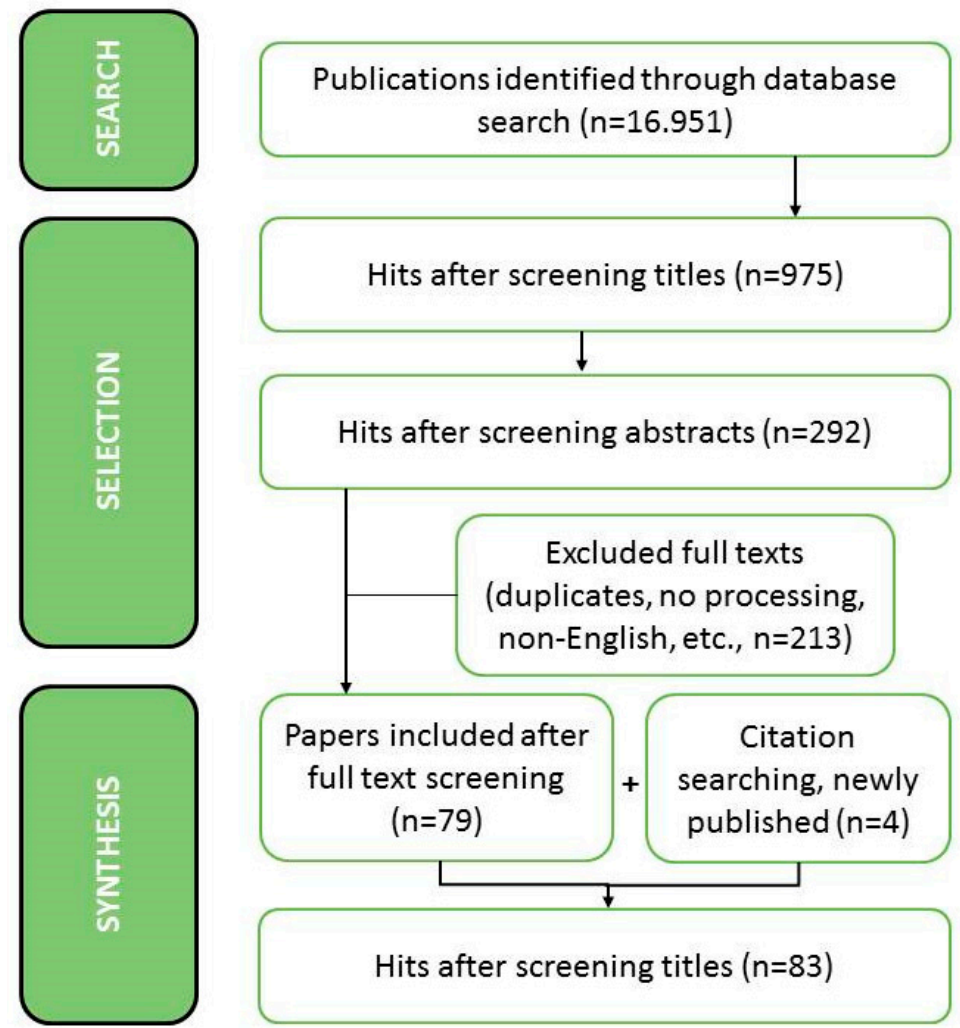

Figure 1. Flowchart illustrating the literature search and selection process.

Data was extracted from each identified study using a pre-defined data extraction tool. This included information on the study area, study objectives, data source and collection methods, information on the NTFP product in question, processing activities, value chain characteristics starting 
from raw material acquisition to final marketing, the institutional environment, ecological, economic, and social impacts, and success factors, constraints, and recommendations as stated by the authors. The rationale for the data categories included was based on recommendations by Belcher and Pérez 2001 [78], but was refined to suit the study objectives. Because of data limitations, the quantification of effects due to processing activities (meta-analysis) could not be conducted. Therefore, textual data was analyzed using the qualitative data analysis tool MAXQDA 2018, coding present enabling and constraining factors of NTFP processing [79]. The factors identified were then categorized into common themes and grouped according to their scale (raw material, product, enterprise, market, value chain, and macro level). Besides success and constraining factors, negative environmental implications and strategies to overcome these were considered. In a second step, the identified studies were categorized according to the level of commercialization, whereas four different categories were distinguished (Table 2). The studies were then evaluated against identified factors for success, following the principle that only when the factor was clearly stated as present by the respective authors was the study included in the frequency analysis.

Table 2. Categorization of the studies identified on NTFP processing.

\begin{tabular}{|c|c|c|}
\hline Category of Commercialization & Characterization & No. of Studies \\
\hline \multirow{3}{*}{ low } & NTFP source: wild & \multirow{3}{*}{30} \\
\hline & Market: regional & \\
\hline & Processing: only limited value addition, simple tools & \\
\hline \multirow{3}{*}{ medium-A } & NTFP source: cultivation (at least partly) & \multirow{3}{*}{11} \\
\hline & Market: regional & \\
\hline & Processing: only limited value addition, simple tools & \\
\hline \multirow{3}{*}{ medium-B } & NTFP source: wild & \multirow{3}{*}{19} \\
\hline & Market: export and/or national & \\
\hline & Processing: only limited value addition, simple tools & \\
\hline \multirow{3}{*}{ high } & $\begin{array}{l}\text { At least two of the following: } \\
\text { NTFP source: cultivation (at least partly) }\end{array}$ & \multirow{3}{*}{27} \\
\hline & Market: export and/or national & \\
\hline & Processing: professional, mechanized value addition & \\
\hline
\end{tabular}

\section{Results}

\subsection{An Overview of the NTFP Studies}

The identified articles were published between 1989 and 2019 (Figure 2). However, over 70\% of the studies were published from 2011 onwards, indicating the rising scholarly interest in NTFP commercialization. Almost half of the articles $(n=39)$ were based on studies in Africa. Next were articles from Asia $(n=17)$ and South America $(n=13)$, whereas relatively few articles featured studies from Europe, North America, or Australia. A total of 73 different NTFP species were investigated; however, 28 articles did not provide in-depth taxonomic information on the species utilized. The most commonly investigated, processed NTFP species included the Brazil nut Bertholletia excelsa Bonpl. [80-82]; the processed kernels of Ricinodendron heudelotii (Baill.) Heckel, which are used as a flavoring agent [83-86]; butter derived from the fruits of the shea tree Vitellaria paradoxa C.F.Gaertn. [87-89]; and beverages made from the fruits of the Marula tree Sclerocarya birrea (A.Rich.) Hochst. [90-92]. Besides food products, the articles also encompassed a wide variety of other product categories, including different types of household goods (e.g., brushes and brooms, baskets and handbags, mats, ropes, etc.), artwork, and cosmetic products (Table 3). These findings are in line with the often-cited diverse nature of NTFPs. In approximately half of the case studies, the NTFP collectors were directly involved in processing activities, although these were typically only basic value-addition activities. In other cases, more or less formal arrangements with processors were observed. In over $70 \%$ of the studies, NTFPs originated from 
wild sources; approximately $11 \%$ were cultivated and $17 \%$ stemmed from both cultivated and wild sources. Approximately half of end products were targeted solely towards local and regional markets; $26 \%$ of NTFPs targeted export markets; and the remaining either national markets $(6 \%)$ or a mixture of domestic and export markets (18\%). More commonly identified processed NTFPs targeted niche markets (57\%) in comparison to mass markets (43\%). In roughly a third of the case studies identified, NTFP development received external support, most commonly through development initiatives.

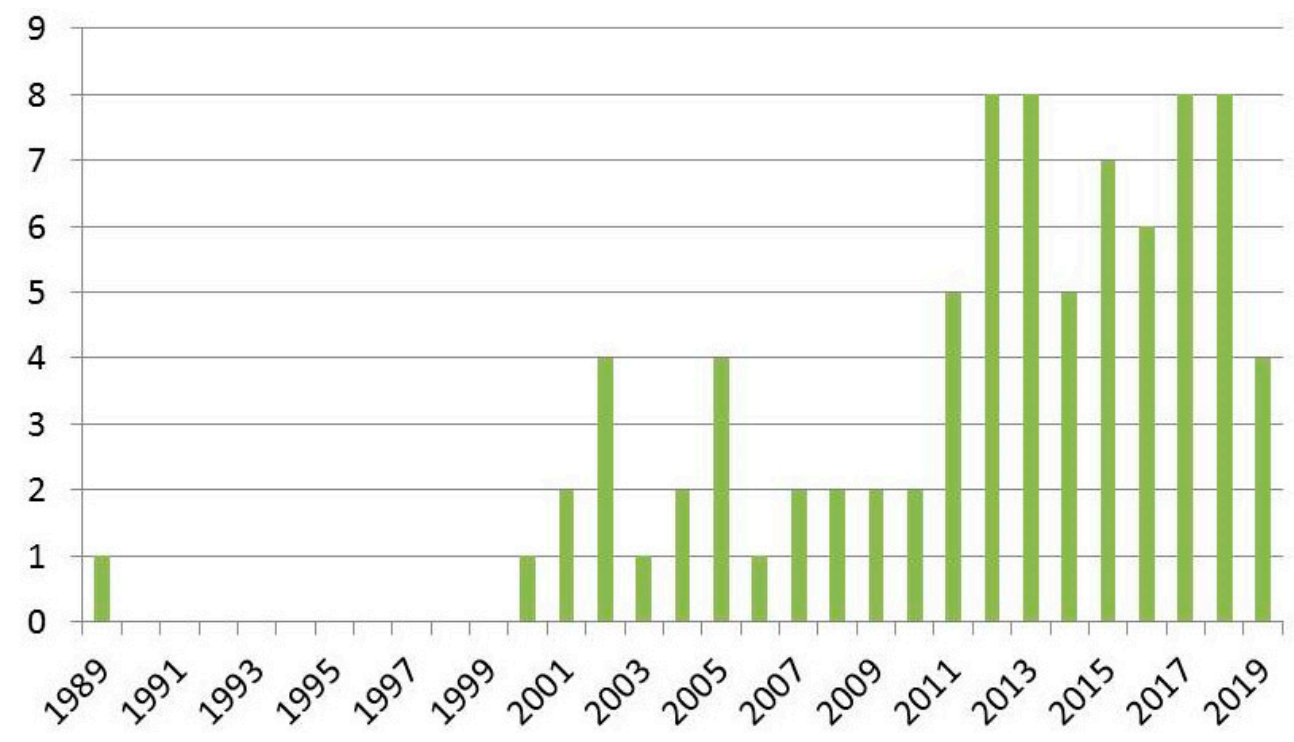

Figure 2. Number of articles per year.

Table 3. Overview of identified commercialized and processed NTFPs.

\begin{tabular}{|c|c|c|c|c|}
\hline Product Category & NTFP Product & Species & Countries & References \\
\hline \multirow{7}{*}{$\begin{array}{l}\text { Foodstuff } \\
(n=33)\end{array}$} & Honey & $\begin{array}{l}\text { Apis mellifera Linnaeus, Apis } \\
\text { dorsata Fabricius. }\end{array}$ & $\begin{array}{l}\text { Cameroon, Ethiopia, Kenya, } \\
\text { Philippines }\end{array}$ & [93-98] \\
\hline & Mushrooms & $\begin{array}{l}\text { Various, such as Boletus spp. } \\
\text { (often not specified) }\end{array}$ & Finland, Italy & {$[101,102]$} \\
\hline & Tea & $\begin{array}{l}\text { Ilex guayusa Loes., different herbs } \\
\text { (often not specified) }\end{array}$ & Ecuador, European countries & [104-106] \\
\hline & Nuts, Seeds & $\begin{array}{l}\text { Bertholletia excelsa Bonpl., Cola } \\
\text { anomala K.Schum. }\end{array}$ & Bolivia, Cameroon, Peru & {$[81,82,85]$} \\
\hline & $\begin{array}{l}\text { Alcoholic } \\
\text { beverages }\end{array}$ & $\begin{array}{l}\text { Elaeis guineensis Jacq., Hyphaene } \\
\text { coriacea Gaertn., or Phoenix } \\
\text { reclinata Jacq. (Palm wine) }\end{array}$ & Mozambique, Sierra Leone & {$[108,109]$} \\
\hline & Bamboo shoots & Bambusa spp. & China & {$[110]$} \\
\hline & Various & $\begin{array}{l}\text { Various (mixture of mushrooms, } \\
\text { honey, forest berries, etc.) }\end{array}$ & $\begin{array}{l}\text { Cameroon, European } \\
\text { countries }\end{array}$ & $\begin{array}{l}{[105,106,111] ;} \\
{[112,113]}\end{array}$ \\
\hline
\end{tabular}


Table 3. Cont.

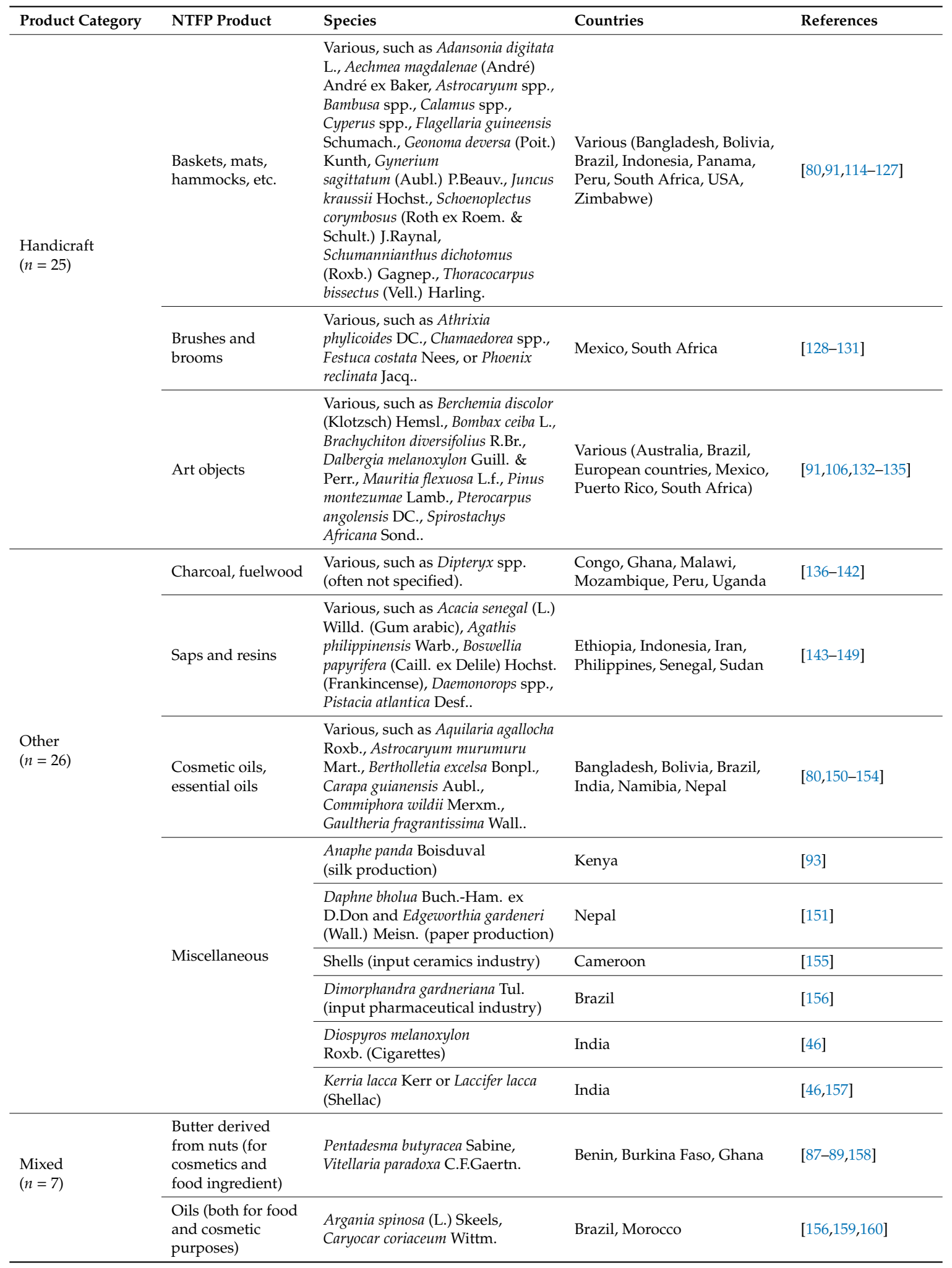

\subsection{Identification of Enabling and Constraining Factors}

Despite the diverse nature of NTFPs, recurrent factors for success and failure can be distinguished. An overall enabling environment for successful NTFP processing has been derived, categorizing the factors identified across the value chain while considering the broader institutional environment 
(Figure 3). In the following sections, enabling and constraining factors of NTFP processing at critical points of the value chain, their respective degrees of importance, and potential pathways of intervention are presented.

\section{NTFP processing enterprise}

- Entrepreneurial spirit

- Technical, business, market knowledge

- Financial resources available/accessible

- Cooperation with other businesses, as well as members from the value chain members and of broader institutional environment
Institutional Framework

- Supportive regulatory framework in place and enforced

- Technical, financial, and institutional support available/accessible

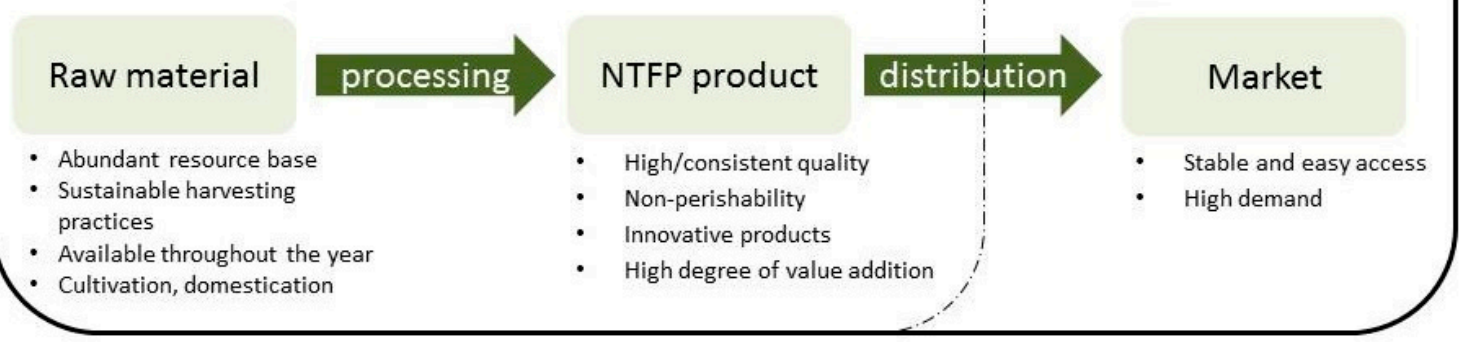

Figure 3. The enabling environment for successful NTFP processing.

\subsubsection{Raw Material Acquisition}

An abundant NTFP resource base is a prerequisite for the further development of the industry. This can be complicated by the fact that many NTFP species such as fruits or mushrooms are seasonal which is obstructive for business development-in particular, when processing cannot increase the shelf life of the product. Nevertheless, some NTFP species are available throughout the year, including selected materials for handicrafts [134] or for the production of palm wine [109]. In any case, harvesting activities should not compromise the resource base, should have minimal environmental implications, and should not imply health threats (e.g., due to conflicts with wildlife or climbing of trees [128]). Furthermore, subsistence use of the local population should not be compromised by NTFP harvesting for commercial purposes [161].

Unfortunately, however, resource scarcity due to overharvesting and unsustainable harvesting practices is a common problem in the sector. Although the environmental implications of NTFP harvesting and processing were not the main focus of the articles identified, over $40 \%$ mentioned negative ecological effects-most commonly, overexploitation of the resource in question. Increased harvesting pressure due to high demand of the resource and unsustainable harvesting techniques, such as destructive harvesting [126,127] or harvesting before sexual reproduction is reached [107], can lead to an overall decline of the resource and a lower productivity of the NTFP species in question. The harvesting pressure can be exacerbated due to potentially substantial post-harvest losses caused by a lack of or inappropriate storage facilities which may lead to insect infestation or microbiological contamination. Indirect negative environmental implications can occur as well, such as the need for other natural resources, in particular firewood, for processing activities $[87,107]$ or pollution and hunting during NTFP harvesting trips [97], leading to further environmental degradation.

Different pathways exist which may assist in overcoming such raw material challenges. These include the cultivation and/or domestication of the resource and having a supportive regulatory framework in place addressing the access and management of the NTFP in question. Replacing traditional NTFP gathering from wild sources by plantations is a common feature in more intensely managed NTFP value chains. Cultivation can take place in various forms, including the integration of NTFP species into agricultural production systems, particularly agroforestry systems, the use of fallow lands or planting NTFPs in publicly or privately owned primary and secondary forests. Besides causing less environmental damage, NTFP cultivation is associated with a variety of other benefits. 
Cultivated NTFP species can more easily be taken care of [126], time requirements for harvesting may be reduced, and having clear access rights in place can improve harvest success and reduce the potential for social conflict [103]. Thus, cultivation of NTFPs can improve the overall return of efforts [130]. However, with regard to species conservation, the benefits of cultivation may not be as straightforward as expected [162]. Agroforestry tree domestication has made great progress in the last decades, and it is seen as an important contributor for enhanced economic returns $[55,163,164]$. NTFP species for which domestication efforts have been initiated include, for example, Ricinodendron heudelotii and Cola anomala [85].

Besides cultivation and domestication efforts, a supportive regulatory framework ranging from national and international laws and regulations to informal rules within the communities involved can improve the access and sustainable management of NTFPs. Although NTFP-specific laws seldom exist, basic frameworks with regard to the import, export, or transit of wild plant species and their derivatives can provide guidance, in particular, where protected species are concerned. Regulations which are too stringent, such as the European Union's Novel Food Regulation (NFR), however, may be too high a burden and discourage investment in supply chains and market development [165].

Tenure rights are of particular importance, since NTFPs are often harvested from the wild. Although the open access of the resource is often a starting point for NTFP collection and business development, case studies emphasize the increased risk of overharvesting and resource scarcity under such conditions (e.g., $[116,149]$ ) and social conflict; e.g., due to competition amongst resource collectors $[90,145]$. With clear ownership arrangements in place, problems and conflicts occurring due to the open access of the resource can be reduced $[100,166]$. For selected, often high-value NTFPs, specific management plans have been developed which provide guidance on sustainable management, in particular harvesting practices (e.g., [82,97,108,130,141,142,145,150,160]). Strategies included strongly vary depending on the resource; however, common principles include preference for non-destructive, minimal impact harvesting and spatial and/or temporal regeneration periods. Commercial collection of NTFPs is often also regulated by collection permits which may be granted based on payment of royalties. This may be facilitated by regional or national authorities, particularly forest departments $[102,107,108,124,131]$, but can also occur on a more informal level, such as by the granting of access rights by traditional leaders or councils [86,109]. Scientifically determined maximum sustainable harvest amounts should provide the basis for the number of collection permits provided, although this is seldom the case. Unfortunately, even if regulatory frameworks with regard to NTFP access and management have been put into place, they are often insufficiently implemented. Common problems include high levels of bureaucracy $[106,131,141,142,144]$, a lack of monitoring and low enforcement [131,145], corruption [86], and low levels of awareness and capacity building amongst NTFP collectors.

Ideally, a portion of the profits generated from NTFP commercialization should feed into conservation and/or rural development programs to ensure future availability of the resource and a sustainable development of the sector. This, for instance can be achieved via redistribution of funds obtained from access permits [102] or via afforestation and forest management activities facilitated by NTFP cooperatives $[96,146]$. Unfortunately, profits obtained from NTFP commercialization alone are seldom a sufficient stimulus for conservation of the resource, an exception being the production of honey [94,95].

\subsubsection{NTFP Processing}

Following raw material acquisition, different enabling and constraining factors can also be distinguished at the actual NTFP processing step — both at product level and at the level of the involved enterprise, as illustrated in the following sections. 


\section{Product Characteristics}

Several product parameters can give an indication about the potential of a value-added NTFP. Enabling factors for processed NTFPs include high quality of the end product in question, the innovativeness of the product, and non-perishability. By focusing on achieving high and consistent quality, producers may be able to obtain price premiums; for instance, in export markets where compliance with a variety of quality standards is a basic necessity. Although the degree of possible value addition depends on the NTFP in question [167], a high degree of value addition via processing of NTFPs can in general positively influence income and profits generated $[46,86,119,156]$. Furthermore, the possibility of co-production of multiple products from a single source can increase the total value added [167]. Innovative products, in contrast to traditional and often very similar or even identical products, have the advantage that new and larger markets may be accessed $[105,106,126]$. Products which can be stored for a longer time period can be sold throughout the year; for instance, when a better price can be fetched. This has, for instance, been observed for honey/beeswax [96] and charcoal, which can be used as a savings account [140].

Critical is the prevalence of product substitutes, which may be more appealing to consumers due to, for instance, their cheaper prices, resulting in a generally lower demand for NTFPs. Further constraints include a relatively low or variable product quality, perishable products, products lacking innovation, or only basic value addition. NTFP value addition often remains limited due to financial constraints reducing the economic impact that could be achieved. Traditional, often cumbersome processing with basic, outdated equipment also may not achieve the quality demanded by higher return markets, as demonstrated, for instance, for shea butter [88], Brazil nuts [82], bush mangos [103], attar oil [154], and argan oil [160].

\section{Enterprise Characteristics}

The entry into the NTFP sector is often seen as relatively easy with only few requirements in terms of resource needs and skills. Furthermore, labor is often readily available, enhanced by the fact that opportunities for wage labor are often limited in rural areas with high dependencies on NTFPs. However, in order to be successful in the market and grow, different skill sets are needed, including technical know-how for processing —in particular to reach higher quality standards-and business skills and market knowledge [105]. Such skill sets and knowledge can be obtained by prior experiences in similar businesses $[105,106]$ and through targeted capacity building initiatives, which are often included in NTFP development initiatives. Such training can contribute to helping producers meet quality requirements by improved storage and processing technologies $[82,96,157]$, but also provide the required marketing, business, and organizational skills to successfully run a small-scale enterprise $[123,135,153]$.

Successful NTFP enterprises often also feature a particular entrepreneurial spirit of the founder which can help gain and sustain a competitive advantage. Key entrepreneurs often are a driving force for success and govern entire value chains [168]. Examples for such industry champions include commercializing African honey [95,96] and mushrooms from Finland [102]. Successful entrepreneurs are often characterized by having high levels of personal interest and engagement in the sector and persistence to acquire needed knowledge of business necessities and opportunities [105,106]. Besides industry champions, microenterprises within a traditional NTFP sector featuring higher entrepreneurial flair have been demonstrated to be more successful than others [131].

Cooperation is also considered beneficial for successful small-scale NTFP processing enterprises. By joining marketing groups and cooperatives, knowledge and skills can be shared amongst members, scale and cost inefficiencies can be overcome, and better bargaining power can be obtained for traders, which can potentially result in increased prices [113]. Furthermore, participation in producer cooperatives may have other benefits, such as enhancing feelings of self-worth amongst members [159]. Positive examples exist, e.g., for njansang [85], argan oil [159], Brazil nuts [82], and crafted products [123]. However, effects strongly depend on the cooperative's operating procedures [160], and a scattered 
distribution of producers can also limit the effectiveness of group activities [85]. Besides cooperation with other businesses, cooperation with value chain members, and with members from the broader institutional environment (e.g., research institutes, authorities, NGOs, etc.) can also contribute to business success. Close cooperation and partnerships of NTFP processing enterprises with members of the broader institutional environment, such as local authorities, NGOs, and research institutions can help reduce market inefficiencies and administrative barriers [106]. This has been observed for honey [94-96], Brazil nuts [82], medicinal and aromatic plants [153], and mushrooms [102]. In select cases, such initiatives can even guide the way for new formal standards [95].

The most common constraining factor NTFP processing enterprises face is their limited financial position. Capital requirement for business establishment predominantly stems from own resources [169]. This may make it difficult to invest in e.g., further value addition activities and machinery and thus limit growth and performance of these enterprises, as shown for example for shea [88], argan [160], or agar oil [152]. This can potentially be exacerbated by lack of needed inputs for processing activities, such as fuel wood or electricity. Lack of financial resources can also lead to elite capture, whereas benefits of NTFP commercialization are captured by few, successful enterprises pushing smaller producers out of the market. Poor producers may not afford credit needed between the harvest and sale period [137], do not have resources to cultivate the resource on their lands, but solely rely on increasingly scarce wild sources [116,130,139], cannot afford permits or fees needed for production [143,144], or cannot invest into new technologies with which quality requirement demanded by the market can be reached [160]. Furthermore, small scale producers often have a diversified livelihood strategy in place and may consider it a high risk to invest their limited financial resources solely into NTFPs [104].

Individualistic approaches to business [107,132] and a lack of technical or business skills and particular limited market knowledge are further constraints for NTFP processing enterprises, which may lead to bargaining power remaining with downstream actors [88,97]. Collective NTFP commercialization via associations or cooperatives may not always lead to price premiums, often due to organizational constraints within the cooperatives and mismanagement, discouraging further participation of smallholders $[84,85,98,146,159]$. Collective entrepreneurial capacity and contribution to household economy may vary significantly depending on organizational setup $[170,171]$. Benefits of collective action must be evident for smallholders to participate [95].

\subsubsection{Marketing of Processed NTFPs}

An enabling framework for NTFP processing also features common characteristics on the market level and in value chain setup.

\section{Market Characteristics}

Easy access to markets, both spatially and temporally contributes to business success. This can be facilitated via presence of NGOs and development projects [123,153], however, such initiatives will only be viable in case of sufficient demand of the product. High demand is a prerequisite for NTFP business establishment, as seen for instance for charcoal [137], brooms [131], amarula products [92], or agar oil [154]. Creation of demand often does not go without intense marketing efforts, in particular for novel products entering international markets [104,105], funds for which are often not readily available. Nevertheless, studies have demonstrated that demand potential for NTFP products can be considerable, with quality and environmental friendliness being the most important attributes [172,173]. Projects focusing on NTFP business development without considering the demand may fail since the increased supply of products cannot be absorbed, resulting in low prices of the products $[82,93,104,121,127,153]$. Further constraints persist due to often fluctuating NTFP markets and price oscillations [82,156,159], boom-bust cycles, or the presence of only one or few buyers [93,104]. Under such conditions, it may be too big a risk for small-scale producers to professionalize their NTFP businesses and forsake other income-generating opportunities [95]. 


\section{Value Chain Setup}

Certain value chain setups have been demonstrated to fetch larger benefits for NTFP-processing enterprises. Short value chains are seen as beneficial, since the role of middlemen is restricted and producers can potentially obtain higher prices [100,102,127,149]. Furthermore, shorter chains may also ease implementation and control of standards [104]. The critical role of intermediaries, appropriating benefits and contributing to poor marketing margins for producers has often been demonstrated $[143,145,152]$. However, with limited market information available, poor infrastructure and financial constraints, middlemen may sometimes be the only pathway for producers to access markets at all.

Integrated value chains with close cooperation amongst members are also commonly associated with economic benefits. Close cooperation between collectors and processors may result in cost reduction and ensure that high-quality raw material is sourced; for instance, via setup of collection centers or pick-up events $[101,102,106]$. Such arrangements can also provide collectors with market assurance [147].Via contracts, small-scale producers may be linked to international markets with premium prices improving their income $[94,104]$. Such cooperation may also occur via informal social norms, binding value chain members together, and providing mutual benefits [108]. However, cooperation amongst value chain members should not be seen as a golden bullet, but strongly depends on the respective setting. For instance, small-scale producers may be limited in their economic freedom and left in a subordinate position depending on the conditions set [82]. Furthermore, they may be restricted to low value-added NTFP development, whereas actors further downstream may capture higher profits [97].

\subsubsection{Features of the Broader Institutional Environment}

NTFP governance can be characterized as a complex and dynamic hybrid of institutional arrangements, norms, and collective social practices in a multilevel and multi-actor environment [174]. A supportive legislative framework in place can boost the sector, as demonstrated, for instance, for wild mushrooms in Finland, where tax benefits led to a development of the sector [101]. Creating and enabling a business environment for small and medium forest enterprises can be achieved by adapting land tenure arrangements, coupled with capacity building and support activities [175]. For a variety of often high-value species, NTFP management plans have been developed which may offer an opportunity on a more local scale for the sustainable management and upgrading of the resource; for instance, by providing harvesting rules to avoid overexploitation $[82,120,130,151]$. However, overall supportive legislative and institutional frameworks with regard to NTFPs are often lacking or weak $[93,95,97,106]$. Where regulations with regard to access and marketing NTFPs do exist, lack of law enforcement and corruption are further obstacles to professionalizing NTFP value chains $[86,144,145,176]$. A high level of bureaucracy and unclear or unrealistic procedures to follow also inhibit a further development of the sector $[131,141,142,144]$, particularly since NTFP regulations are often embedded in broader frameworks considering rural development or agriculture [106]. NTFP innovations are typically generated from the bottom-up, due to the limited influence of institutional systems [177].

Such issues may often be further exacerbated by poor infrastructure (in particular roads and electricity), restricting market access and the setting of competitive prices $[86,103,160]$. Necessary technical or financial support from authorities, extension agencies, NGOs, research, and/or financial institutions to assist small-scale producers and to professionalize the sector are often lacking or insufficient $[105,106,112,132]$. Furthermore, capacity building efforts may not be effective per se, as demonstrated, for instance, by beekeeping [94] and Brazil nut processing - with project lifecycles and their limited timeframes further complicating long-term, sustainable development of the sector in question $[82,178]$. Established cooperative enterprises may not be able to sustain themselves once external support is gone [171]. It is, therefore, vital that development initiatives reflect the needs of the sector in question on a case-by-case basis. Positive results have, e.g., been obtained for lac 
production [157], medicinal plant cultivation and marketing [153], Brazil nuts [178], njansang [84], and artwork [132,133]. However, the long-term sustainability of such initiatives often remains to be seen and the personal initiative of each entrepreneur involved is often viewed to be more important $[105,106]$. Through building partnerships, many such NTFP governance challenges can be met [179].

\subsection{Differentiation Depending on Level of Commercialisation}

The frequencies of the selected success factors amongst the case studies reviewed (such as product innovativeness, entrepreneurial spirit of the founder, and the presence of a supportive regulatory framework) differ depending on the intensity of commercialization of processed NTFPs, as categorized in Table 2 (Figure 4).

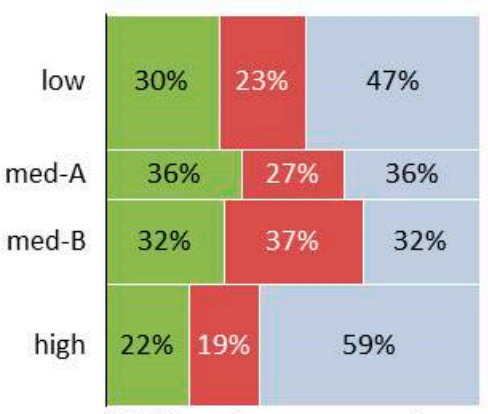

(a) Abundant resource base

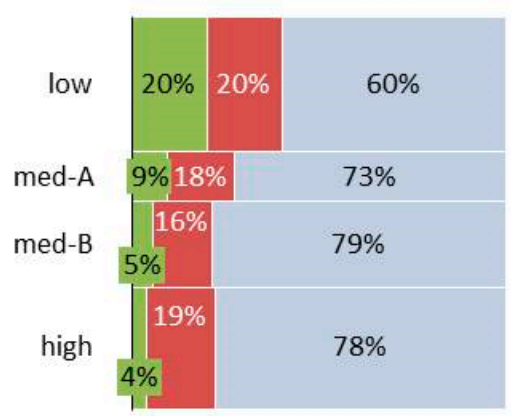

(d) Market proximity, easy access

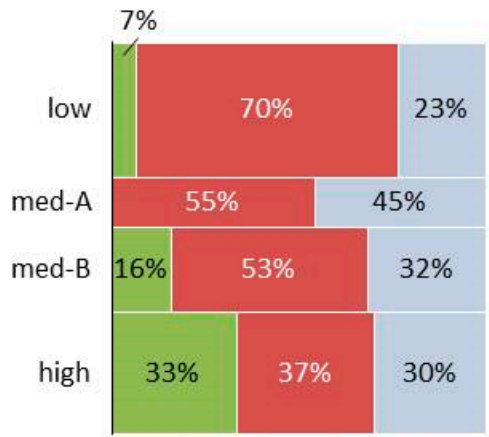

(b) Innovative products

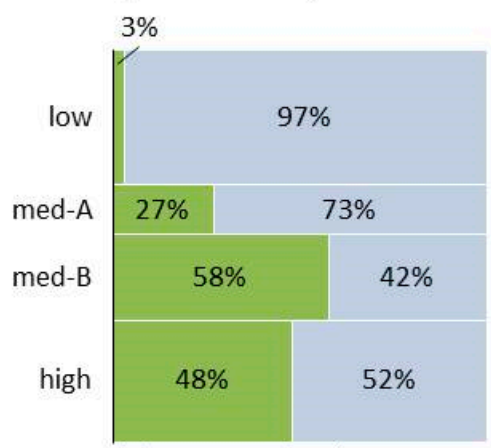

(e) Cooperation between value chain members

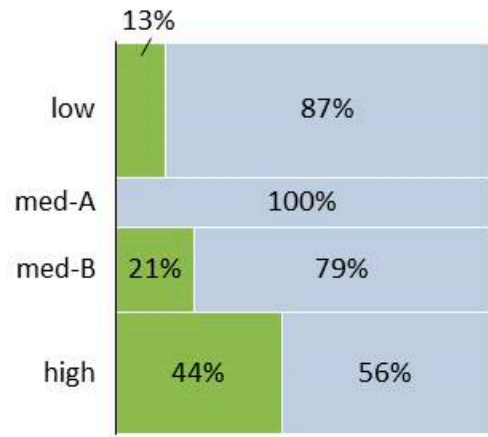

(c) Entrepreneurial spirit

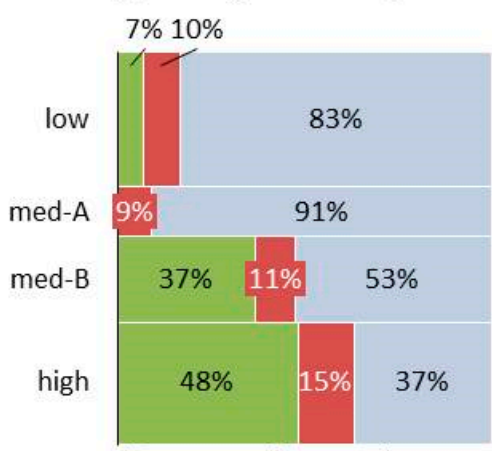

(f) Supportive regulatory framework

Figure 4. Frequency distribution (\%) of selected success factors (panels a-f) depending on level of commercialization (green: factor present in case study; red: factor not present; grey: not sufficient or inconclusive information provided).

Considering the resource base, the data is not very conclusive. Overexploitation of the resource and destructive or unsustainable harvesting practices can occur at all levels of commercialization, although the latter was more present in the lower commercialized categories (low: 20\%, med-A: 36\%, med-B: $10 \%$, and high: $11 \%$ of studies, respectively). Lack of resources in the wild gives a strong incentive for cultivation and sustainable management practices, particularly in cases of strong demand for the product in question, as seen in a number of cases for more highly commercialized NTFPs, such as charcoal production [138-140], juçara berries [99], agar oil production [152,154], chamaedorea palms [130], bamboo products [125], and jernang production [149].

Processed NTFP products commercialized on a low level predominantly are traditional, identical, or very similar products with only limited value addition. Moving towards a higher degree of commercialization, the level of more innovative products increases; however, also in the field of highly commercialized NTFPs, many products have still only undergone basic processing steps $(30 \%$ of studies in the highly commercialized category) with further value addition taking place only in the countries of import. Nevertheless, $40 \%$ of studies in the highly commercialized category indicate that 
reaching high quality is a critical factor for success, whereas quality was of no concern in the low and medium level-of-commercialization studies focusing on regional markets.

With regard to the processing enterprises themselves, the existence of industry champions is more prevalent in the case of more highly commercialized NTFPs and exported goods; however, it can also occur on a regional level with individual SMEs standing out, for instance, due to innovative ideas concerning the marketing of their products. In contrast, elite capture of benefits was shown to occur in all settings (low: $10 \%$, med-A: $27 \%$, med-B: $32 \%$, high: $15 \%$ of studies, respectively). Cooperation with other enterprises and with members from the institutional environment was judged as a positive success factor in approximately $50 \%$ of studies targeting export markets (med-B and high level of commercialization) - in contrast to $23 \%$ in the low level of commercialization category which was mainly due to the formation of cooperatives.

Short value chains are judged to be a successful approach for NTFP products commercialized regionally. When the collection of NTFPs, their processing, and their selling is all performed by the same actors, appropriation of benefits by middlemen can be avoided and higher incomes are achieved by small-scale NTFP processers. With increasing intensity of commercialization and targeting of international markets, cooperation between value chain members gains importance. Successful chains for highly commercialized NTFPs are strongly integrated, e.g., by having contracts in place between different value chain members. However, marketing processed NTFPs internationally is not straightforward, with $25 \%-32 \%$ of studies on exporting NTFPs mentioning fluctuating markets and difficult access as major constraints, and only approximately $5 \%$ mentioning easy market access as a success factor. For lower and regionally commercialized NTFPs, the picture is less clear, with access to markets being judged as an enabling and a constraining factor more evenly across studies, strongly depending on the respective context and product. This holds true for demand of processed NTFP products as well, which is highly dependent on the product in question.

Having a supportive legislative framework in place is more prevalent in case NTFP products are exported, potentially since the importance of the NTFP in question has already been realized and supporting corresponding legislations have been put into place. Furthermore, different quality standards need to be fulfilled. Institutional support, for instance via financial support programs (loans and subsidies), and activities from research agencies, NGOs, and development organizations, is also more prevalent for more highly commercialized NTFPs—although often judged not to be sufficient or difficult to access due to bureaucratic reasons and lack of information.

\section{Discussion}

The literature identified encompasses a broad body of different NTFP species, processing techniques, and products. Overall, the potential for NTFP processing enterprises to benefit from NTFP commoditization varies strongly depending on species and product, value chain set-up, the type of market, etc. No singular true path for successful NTFP processing exists, but interventions need to be context specific. Strategies commonly employed, such as group marketing and other forms of collective action, for instance, can have strongly varying effects [84,170]. Different types of value chain setup and organizational models may be advantageous - even for similar products [102]. Furthermore, it has to be stressed that depicted outcomes need to be seen under the condition that NTFP processing studies are difficult to compare due to the high variability amongst products and contexts. Individually, the studies identified, with their varying aims and objectives, typically addressed only selected aspects of pro-poor NTFP processing, neglecting other important issues. For example, extensive information on cooperation may have been provided, with little attention to raw material issue or product characteristics. This inhibits the potential to draw conclusions on inter-linkages and the level of importance of a respective factor. This is further complicated by varying study designs and use of different indicators across studies [180]. Different methods for calculating the economic importance of NTFPs extracted by rural populations can lead to serious uncertainties [181]. 
Nevertheless, the tendencies revealed are in line with outcomes of other authors who have previously investigated NTFP commercialization. Marshall et al. identified success and constraining factors across the following processes of NTFP commercialization: production, collection, processing, storage, transport, marketing, and sale, with marketing and sale being the key processes constraining successful commercialization [182]. Cunningham identified the need to understand supply chains, consumers, middlemen, prices, roles, and market potential as being of particular importance [43]. Highlighted constraints included the inability to get large volumes to meet market demand, and a lack of attention to quality, quantity, and on-time production. Furthermore, Cunningham et al. identified key barriers of NTFP enterprises to enter commercial markets as resource base, capital, scale, quality, market knowledge, trade network, inventory turnover, policy and regulation, marketing partners, and producer support needs [183]. Badini et al. identified and characterized twelve critical success factors of enabling business environments for forest SMEs as macroeconomic setting, regulatory frameworks, forest law enforcement, tenure and ownership rights, management and land use planning rights, markets, natural capital, financial capital, forest management capacities, business management capacities, organizational capacities, and clustering [184]. Macqueen et al. highlights the importance of democratic oversight, bodies governing environmental and cultural stewardship, negotiated benefit distribution and financial vigilance mechanisms, networks for better access to markets and decision-making, processes for conflict resolution and justice, processes of entrepreneurial training and empowerment, and branding that reinforces local visions of prosperity, as success factors for locally-controlled forestry businesses [185]. According to Pettenella et al., the differentiation, integration, and creation of networking among both private and public actors and the development of the territorial marketing are considered the most important tools for improving the economic value of small-scale forestry in marginal areas-without leaving the resource base overlooked [186]. Newton established five conditions necessary in order to achieve the sustainable use of NTFPs: the harvesting of forest products must be sustainable and must not interact positively with other threats; commercialization of the forest product must be economically viable; economic benefits from commercialization must be received by producers; and the income received from commercialization must support conservation action [40]. Shackleton and Pandey propose eight steps to facilitate integration of NTFPs for the benefit of local communities: proper inventory of NTFP stocks; research on NTFP ecology and sustainable harvest levels; the introduction of extension services for NTFPs; the inclusion of NTFPs in land management and trade-off decisions; the integration of NTFPs into sectoral policies; ensuring NTFP commercialization does not inhibit local livelihood needs; promoting security of access and use; and finally, the examination of local contextual drivers of unsustainable use [187].

Focusing on NTFP processing, the importance of the development and promotion of small-scale processing technologies in order to achieve high-quality products with longer shelf lives needs to be highlighted. Processed NTFP products often remain traditional, although there is great potential for innovative products with higher degrees of value addition, given the increasing consumer demand for specialty products and the variety of NTFPs. Nevertheless, open questions remain, such as when and how, with increasing commercialization, NTFPs are transformed from being extracted products to being included into more advanced, industrial production systems. How this transition will affect local consumption and use patterns, and whether and under which circumstances cultivation and extractivism can occur in parallel or at the risk of exclusion or marginalization of smallholders in this context are further issues to be more deeply investigated in the future. Furthermore, the effects of individual in contrast to collective actions at different stages of the value chain (harvesting, processing, marketing, etc.) need to be more fully addressed.

\section{Conclusions}

It needs to be emphasized that the enabling framework illustrated for successful NTFP processing cannot provide a straightforward pathway for NTFP commercialization, but rather draws attention to key issues when, for instance, planning NTFP development initiatives. While NTFP value chains 
may seem rather straightforward, there may be considerable complexities and challenges involved which may inhibit upstream actors from fully benefiting from commercialization activities. Policy support to enhance the successful processing of NTFPs, thus, needs to be tailored to the respective contexts and value chains. The potential of an NTFP is not solely characterized by the product itself, but also by its socio-economic and environmental context, taking the entire value chain and the surrounding institutional framework into account [188]. Hence, a nuanced and holistic view needs to be emphasized [38].

Furthermore, it should be stressed that use of NTFPs for subsistence and their safety net function may be of higher importance than their role in creation of job opportunities and contributing to rural development [189]. In order to stimulate benefits, NTFP commercialization needs to generate sufficient profits for re-investment-which is most often not the case. This may be complicated by the fact that benefits from NTFP commercialization can be captured by elites. Nevertheless, the processing of NTFPs can raise income levels and provide a stepping stone out of poverty for some in selected contexts and circumstances. Last but not least, it should not be overlooked that NTFP commodification has other benefits as well, such as contributing to livelihood diversification, enhancing the self-worth of producers, and providing an opportunity to enter the cash economy in the first place, particularly in rural settings with limited options for wage labor.

Author Contributions: Conceptualization: K.M. and D.D.; methodology: K.M. and D.D.; validation: K.M. and D.D.; formal analysis: K.M.; investigation: K.M. and D.D.; data curation: K.M.; writing—original draft preparation: K.M.; writing — review and editing: D.D.; visualization: K.M.; supervision, D.D.

Funding: This work was financially supported by the German Federal Ministry of Food and Agriculture (BMEL) based on the decision of the Parliament of the Federal Republic of Germany through the Federal Office for Agriculture and Food (BLE), grant number 2813 FSNU07.

Conflicts of Interest: The authors declare no conflict of interest.

\section{References}

1. Angelsen, A.; Jagger, P.; Babigumira, R.; Belcher, B.; Hogarth, N.J.; Bauch, S.; Börner, J.; Smith-Hall, C.; Wunder, S. Environmental Income and Rural Livelihoods: A Global-Comparative Analysis. World Dev. 2014, 64, 12-28. [CrossRef]

2. Babulo, B.; Muys, B.; Nega, F.; Tollens, E.; Nyssen, J.; Deckers, J.; Mathijs, E. The economic contribution of forest resource use to rural livelihoods in Tigray, Northern Ethiopia. For. Policy Econ. 2009, 11, 109-117. [CrossRef]

3. Cavendish, W. Empirical Regularities in the Poverty-Environment Relationship of Rural Households: Evidence from Zimbabwe. World Dev. 2000, 28, 1979-2003. [CrossRef]

4. Delang, C.O. Not just minor forest products: The economic rationale for the consumption of wild food plants by subsistence farmers. Ecol. Econ. 2006, 59, 64-73. [CrossRef]

5. Kar, S.P.; Jacobson, M.G. NTFP income contribution to household economy and related socio-economic factors: Lessons from Bangladesh. For. Policy Econ. 2012, 14, 136-142. [CrossRef]

6. Lacuna-Richman, C. Subsistence strategies of an indigenous minority in the Philippines: Nonwood forest product use by the Tagbanua of Narra, Palawan. Econ. Bot. 2004, 58, 266-285. [CrossRef]

7. Mahapatra, A.K.; Tewari, D.D. Importance of non-timber forest products in the economic valuation of dry deciduous forests of India. For. Policy Econ. 2005, 7, 455-467. [CrossRef]

8. Mahapatra, A.K.; Panda, P.C. Wild edible fruit diversity and its significance in the livelihood of indigenous tribals: Evidence from eastern India. Food Secur. 2012, 4, 219-234. [CrossRef]

9. Malleson, R.; Asaha, S.; Egot, M.; Kshatriya, M.; Marshall, E.; Obeng-Okrah, K.; Sunderland, T. Non-timber forest products income from forest landscapes of Cameroon, Ghana and Nigeria-An incidental or integral contribution to sustaining rural livelihoods? Int. For. Rev. 2014, 16, 261-277. [CrossRef]

10. Mugido, W.; Shackleton, C.M. The contribution of NTFP trade to rural livelihoods in different agro-ecological zones of South Africa. Int. For. Rev. 2017, 19, 306-320. [CrossRef]

11. Oñate-Calvín, R.; de Oviedo, J.L.; Salo, M. Forest Resource-based Household Economy in the Communities of the Nanay River Basin, Peruvian Amazonia. Ecol. Econ. 2018, 146, 218-227. [CrossRef] 
12. Shackleton, C.; Shackleton, S. The importance of non-timber forest products in rural livelihood security and as safety nets: A review of evidence from South Africa. S. Afr. J. Sci. 2004, 100, 658-664.

13. Shackleton, C.M.; Shackleton, S.E.; Buiten, E.; Bird, N. The importance of dry woodlands and forests in rural livelihoods and poverty alleviation in South Africa. For. Policy Econ. 2007, 9, 558-577. [CrossRef]

14. Vedeld, P.; Angelsen, A.; Bojö, J.; Sjaastad, E.; Kobugabe Berg, G. Forest environmental incomes and the rural poor. For. Policy Econ. 2007, 9, 869-879. [CrossRef]

15. Cotta, J.N. Contributions of local floodplain resources to livelihoods and household income in the Peruvian Amazon. For. Policy Econ. 2015, 59, 35-46. [CrossRef]

16. Nielsen, M.R.; Pouliot, M.; Kim Bakkegaard, R. Combining income and assets measures to include the transitory nature of poverty in assessments of forest dependence: Evidence from the Democratic Republic of Congo. Ecol. Econ. 2012, 78, 37-46. [CrossRef]

17. Rijal, A.; Smith-Hall, C.; Helles, F. Non-timber forest product dependency in the Central Himalayan foot hills. Environ. Dev. Sustain. 2011, 13, 121-140. [CrossRef]

18. Shackleton, C.M.; Shackleton, S.E. Household wealth status and natural resource use in the Kat River valley, South Africa. Ecol. Econ. 2006, 57, 306-317. [CrossRef]

19. Barany, M.; Hammett, A.L.; Stadler, K.M.; Kengni, E. Non-Timber Forest Products in the food security and nutrition of smallholders afflicted by HIV/AIDS in Sub-Saharan Africa. For. Trees Livelihoods 2004, 14, 3-18. [CrossRef]

20. Bvenura, C.; Afolayan, A.J. The role of wild vegetables in household food security in South Africa: A review. Food Res. Int. 2015, 76, 1001-1011. [CrossRef]

21. Saka, J.D.K.; Kadzere, I.; Ndabikunze, B.K.; Akinnifesi, F.K.; Tiisekwa, B.P.M. Product development: Nutritional value, processing and utilization of indigenous fruits from the Miombo ecosystem. In Indigenous Fruit Trees in the Tropics: Domestication, Utilization and Commercialization; Akinnifesi, F.K., Leakey, R.R.B., Ajayi, O.C., Sileshi, G., Tchoundjeu, Z., Matakala, P., Eds.; CAB International Publishing: Wallingford, UK, 2007; pp. 288-309.

22. Mugido, W.; Shackleton, C.M. The safety net function of NTFPs in different agro-ecological zones of South Africa. Popul. Environ. 2017, 39, 107-125. [CrossRef]

23. Paumgarten, F.; Shackleton, C.M. The role of non-timber forest products in household coping strategies in South Africa: The influence of household wealth and gender. Popul. Environ. 2011, 33, 108. [CrossRef]

24. Völker, M.; Waibel, H. Do rural households extract more forest products in times of crisis? Evidence from the mountainous uplands of Vietnam. For. Policy Econ. 2010, 12, 407-414. [CrossRef]

25. Weyer, D.; Shackleton, C.M.; Adam, Y.O. HIV/AIDS and other household shocks as catalysts of local commercialization of non-timber forest products in Southern Africa. Dev. Policy Rev. 2018, 36, O285-O301. [CrossRef]

26. Woittiez, L.S.; Rufino, M.C.; Giller, K.E.; Mapfumo, P. The Use of Woodland Products to Cope with Climate Variability in Communal Areas in Zimbabwe. Ecol. Soc. 2013, 18, 24. [CrossRef]

27. Zenteno, M.; Zuidema, P.A.; Jong, W.; de Boot, R.G.A. Livelihood strategies and forest dependence: New insights from Bolivian forest communities. For. Policy Econ. 2013, 26, 12-21. [CrossRef]

28. Paumgarten, F.; Locatelli, B.; Witkowski, E.T.F. Wild Foods: Safety Net or Poverty Trap? A South African Case Study. Hum. Ecol. 2018, 46, 183-195. [CrossRef]

29. Wunder, S.; Börner, J.; Shively, G.; Wyman, M. Safety Nets, Gap Filling and Forests: A Global-Comparative Perspective. World Dev. 2014, 64, 29-42. [CrossRef]

30. Fandohan, B.; Assogbadjo, A.E.; Kakaï, R.G.; Kyndt, T.; Caluwé, E.D.; Codjia, J.T.C.; Sinsin, B. Women's Traditional Knowledge, Use Value, and the Contribution of Tamarind (Tamarindus indica L.) to Rural Households' Cash Income in Benin. Econ. Bot. 2010, 64, 248-259. [CrossRef]

31. Worku, A.; Pretzsch, J.; Kassa, H.; Auch, E. The significance of dry forest income for livelihood resilience: The case of the pastoralists and agro-pastoralists in the drylands of southeastern Ethiopia. For. Policy Econ. 2014, 41, 51-59. [CrossRef]

32. Mahapatra, A.K.; Albers, H.J.; Robinson, E.J.Z. The impact of NTFP sales on rural households' cash income in India's dry deciduous forest. Environ. Manag. 2005, 35, 258-265. [CrossRef] [PubMed]

33. Awono, A.; Eba'a Atyi, R.; Foundjem-Tita, D.; Levang, P. Vegetal non-timber forest products in Cameroon, contribution to the national economy. Int. For. Rev. 2016, 18, 66-77. [CrossRef] 
34. Dlamini, C.S.; Geldenhuys, C.J. The socioeconomic status of the non-timber forest product subsector in Swaziland. South. For. 2009, 71,311-318. [CrossRef]

35. Jensen, A. Valuation of non-timber forest products value chains. For. Policy Econ. 2009, 11, 34-41. [CrossRef]

36. Arnold, J.E.M.; Perez, M.R. Can non-timber forest products match tropical forest conservation and development objectives? Ecol. Econ. 2001, 39, 437-447. [CrossRef]

37. Dejene, T.; Lemenih, M.; Bongers, F. Manage or convert Boswellia woodlands? Can frankincense production payoff? J. Arid Environ. 2013, 89, 77-83. [CrossRef]

38. Belcher, B.; Schreckenberg, K. Commercialisation of Non-timber Forest Products: A Reality Check. Dev. Policy Rev. 2007, 25, 355-377. [CrossRef]

39. Kusters, K.; Achdiawan, R.; Belcher, B.; Perez, M.R. Balancing development and conservation? An assessment of livelihood and environmental outcomes of nontimber forest product trade in Asia, Africa, and Latin America. Ecol. Soc. 2006, 11. [CrossRef]

40. Newton, A.C. Conservation of tree species through sustainable use: How can it be achieved in practice? Oryx 2008, 42, 195-205. [CrossRef]

41. Ros-Tonen, M.A.F.; Wiersum, K.F. The scope for improving rural livelihoods through non-timber forest products: An evolving research agenda. For. Trees Livelihoods 2005, 15, 129-148. [CrossRef]

42. Shaanker, R.U.; Ganeshaiah, K.N.; Krishnan, S.; Ramya, R.; Meera, C.; Aravind, N.A.; Kumar, A.; Rao, D.; Vanaraj, G.; Ramachandra, J.; et al. Livelihood gains and ecological costs of non-timber forest product dependence: Assessing the roles of dependence, ecological knowledge and market structure in three contrasting human and ecological settings in south India. Environ. Conserv. 2004, 31, 242-253. [CrossRef]

43. Cunningham, A.B. Non-timber Products and Markets: Lessons for Export-Oriented Enterprise Development from Africa. In Non-Timber Forest Products in the Global Context; Shackleton, S., Shackleton, C., Shanley, P., Eds.; Springer: Berlin/Heidelberg, Germany, 2011.

44. Boxall, P.C.; Murray, G.; Unterschultz, J.R.; Boxall, P.C. Non-timber forest products from the Canadian boreal forest: An exploration of aboriginal opportunities. J. For. Econ. 2003, 9, 75-96. [CrossRef]

45. Charles Aworh, O. Promoting food security and enhancing Nigeria's small farmers' income through value-added processing of lesser-known and under-utilized indigenous fruits and vegetables. Food Res. Int. 2015, 76, 986-991. [CrossRef]

46. Mahapatra, A.K.; Shackleton, C.M. Exploring the relationships between trade in natural products, cash income and livelihoods in tropical forest regions of Eastern India. Int. For. Rev. 2012, 14, 62-73. [CrossRef]

47. Nevenimo, T.I.O.; Johnston, M.; Binifa, J.; Gwabu, C.; Angen, J.; Moxon, J.; Leakey, R. Domestication potential and marketing of Canarium Indicum nuts in the pacific: Producer and consumer surveys in papua new guinea (East New Britain). For. Trees Livelihoods 2008, 18, 253-269. [CrossRef]

48. Scherr, S.J.; White, A.; Kaimowitz, D. A New Agenda for Forest Conservation and Poverty Reduction. Making Forest Markets Work for Low-income Producers; Forest Trends: Washington, DC, USA, 2003.

49. Sundriyal, M.; Sundriyal, R.C. Wild Edible Plants of the Sikkim Himalaya: Marketing, Value Addition and Implications for Management. Econ. Bot. 2004, 58, 300-315. [CrossRef]

50. Tewari, D.D. Income and Employment Generation Opportunities and Potential of Non-Timber Forest Products (NTFPs). J. Sustain. For. 1998, 8, 55-76. [CrossRef]

51. Tieguhong, J.C.; Ndoye, O.; Grouwels, S.; Mala, W.A.; Betti, J.L. Rural enterprise development for poverty alleviation based on non-wood forest products in Central Africa. Int. For. Rev. 2012, 14, 363-379. [CrossRef]

52. Ham, C.; Akinnifesi, F.K.; Franzel, S.; Du Jordaan, D.P.S.; Hansmann, C.; Ajayi, O.C.; de Kock, C. Opportunities for commercialization and enterprise development of indigenous fruits in southern Africa. In Indigenous Fruit Trees in the Tropics: Domestication, Utilization and Commercialization; Akinnifesi, F.K., Leakey, R.R.B., Ajayi, O.C., Sileshi, G., Tchoundjeu, Z., Matakala, P., Eds.; CAB International Publishing: Wallingford, UK, 2007; pp. 254-272.

53. Jordaan, D.; Akinnifesi, F.K.; Ham, C.; Ajayi, O.C. The feasibility of small-scale indigenous fruit processing enterprises in southern Africa. In Indigenous Fruit Trees in the Tropics: Domestication, Utilization and Commercialization; Akinnifesi, F.K., Leakey, R.R.B., Ajayi, O.C., Sileshi, G., Tchoundjeu, Z., Matakala, P., Eds.; CAB International Publishing: Wallingford, UK, 2007; pp. 273-287.

54. Shackleton, C.; Delang, C.O.; Shackleton, S.; Shanley, P. Non-timber Forest Products: Concept and Definitions. In Non-Timber Forest Products in the Global Context; Shackleton, S., Shackleton, C., Shanley, P., Eds.; Springer: Berlin/Heidelberg, Germany, 2011. 
55. Leakey, R.; van Damme, P. The role of tree domestication in green market product value chain development. For. Trees Livelihoods 2014, 23, 116-126. [CrossRef]

56. Albers, H.J.; Robinson, E.J.Z. A review of the spatial economics of non-timber forest product extraction: Implications for policy. Ecol. Econ. 2013, 92, 87-95. [CrossRef]

57. Brites, A.D.; Morsello, C. Ecological Effects of Non-Timber Forest Products Harvest and Trade: A Systematic Review. Desenvol. E Meio Ambiente 2016, 36, 55-72. [CrossRef]

58. Leão, T.C.C.; Lobo, D.; Scotson, L. Economic and Biological Conditions Influence the Sustainability of Harvest of Wild Animals and Plants in Developing Countries. Ecol. Econ. 2017, 140, 14-21. [CrossRef]

59. Schmidt, I.B.; Mandle, L.; Ticktin, T.; Gaoue, O.G. What do matrix population models reveal about the sustainability of non-timber forest product harvest? J. Appl. Ecol. 2011, 48, 815-826. [CrossRef]

60. Stanley, D.; Voeks, R.; Short, L. Is Non-Timber Forest Product Harvest Sustainable in the Less Developed World? A Systematic Review of the Recent Economic and Ecological Literature. Ethnobiol. Conserv. 2012, 1, ec2012-ec2018. [CrossRef]

61. Ticktin, T. The ecological implications of harvesting non-timber forest products. J. Appl. Ecol. 2004, 41, 11-21. [CrossRef]

62. Paumgarten, F. The Role of non-timber forest products as safety-nets: A review of evidence with a focus on South Africa. GeoJournal 2005, 64, 189-197. [CrossRef]

63. Nandal, U.; Bhardwaj, R.L. The Role of Underutilized Fruits in Nutritional and Economic Security of Tribals: A Review. Crit. Rev. Food Sci. Nutr. 2014, 54, 880-890. [CrossRef]

64. Belcher, B.; Ruíz-Pérez, M.; Achdiawan, R. Global patterns and trends in the use and management of commercial NTFPs: Implications for livelihoods and conservation. World Dev. 2005, 33, 1435-1452. [CrossRef]

65. Sunderlin, W.D.; Angelsen, A.; Belcher, B.; Burgers, P.; Nasi, R.; Santoso, L.; Wunder, S. Livelihoods, forests, and conservation in developing countries: An Overview. World Dev. 2005, 33, 1383-1402. [CrossRef]

66. Cheng, S.H.; MacLeod, K.; Ahlroth, S.; Onder, S.; Perge, E.; Shyamsundar, P.; Rana, P.; Garside, R.; Kristjanson, P.; McKinnon, M.C.; et al. A systematic map of evidence on the contribution of forests to poverty alleviation. Environ. Evid. 2019, 8, 3. [CrossRef]

67. Chirwa, P.W.; Syampungani, S.; Geldenhuys, C.J. The ecology and management of the Miombo woodlands for sustainable livelihoods in southern Africa: The case for non-timber forest products. South. For. 2008, 70, 237-245. [CrossRef]

68. Dawson, I.K.; Leakey, R.; Clement, C.R.; Weber, J.C.; Cornelius, J.P.; Roshetko, J.M.; Vinceti, B.; Kalinganire, A.; Tchoundjeu, Z.; Masters, E.; et al. The management of tree genetic resources and the livelihoods of rural communities in the tropics: Non-timber forest products, smallholder agroforestry practices and tree commodity crops. For. Ecol. Manag. 2014, 333, 9-21. [CrossRef]

69. Djoudi, H.; Vergles, E.; Blackie, R.R.; Koame, C.K.; Gautier, D. Dry forests, livelihoods and poverty alleviation: Understanding current trends. Int. For. Rev. 2015, 17, 54-69. [CrossRef]

70. Kaushal, K.K.; Melkani, V.K. India: Achieving the Millennium Development Goals through non-timber forest products. Int. For. Rev. 2005, 7, 128-134. [CrossRef]

71. Reed, J.; van Vianen, J.; Foli, S.; Clendenning, J.; Yang, K.; MacDonald, M.; Petrokofsky, G.; Padoch, C.; Sunderland, T. Trees for life: The ecosystem service contribution of trees to food production and livelihoods in the tropics. For. Policy Econ. 2017, 84, 62-71. [CrossRef]

72. Timko, J.A.; Waeber, P.O.; Kozak, R.A. The socio-economic contribution of non-timber forest products to rural livelihoods in Sub-Saharan Africa: Knowledge gaps and new directions. Int. For. Rev. 2010, 12, $284-294$. [CrossRef]

73. Wahlen, C.B. Opportunities for making the invisible visible: Towards an improved understanding of the economic contributions of NTFPs. For. Policy Econ. 2017, 84, 11-19. [CrossRef]

74. Zulu, L.C.; Richardson, R.B. Charcoal, livelihoods, and poverty reduction: Evidence from sub-Saharan Africa. Energy Sustain. Dev. 2013, 17, 127-137. [CrossRef]

75. Neumann, R.P.; Hirsch, E. Commercialisation of Non-Timber Forest Products. Review and Analysis of Research; CIFOR: Bogor, Indonesia, 2000.

76. Ruiz-Pérez, M.; Belcher, B.; Achdiawan, R.; Alexiades, M.; Aubertin, C.; Caballero, J.; Campbell, B.; Clement, C.; Cunningham, T.; Fantini, A. Markets drive the specialization strategies of forest peoples. Ecol. Soc. 2004, 9, 4. [CrossRef] 
77. Petticrew, M.; Roberts, H. Systematic Reviews in the Social Sciences. A Practical Guide, 12th ed.; Blackwell Publ: Malden, MA, USA, 2012.

78. Belcher, B.; Ruíz Pérez, M. An International Comparison of Cases of Forest Product Development: Overview, Description and Data Requirements 2001; CIFOR: Bogor, Indonesia, 2001.

79. VERBI Software. MAXQDA 2018; VERBI Software: Berlin, Germany, 2018. Available online: https: //www.maxqda.com (accessed on 25 June 2019).

80. Morsello, C.; Ruiz-Mallen, I.; Montoya Diaz, M.D.; Reyes-Garcia, V. The Effects of Processing Non-Timber Forest Products and Trade Partnerships on People's Well-Being and Forest Conservation in Amazonian Societies. PLoS ONE 2012, 7, e43055. [CrossRef]

81. Stoian, D. Making the Best of Two Worlds: Rural and Peri-Urban Livelihood Options Sustained by Non-timber Forest Products from the Bolivian Amazon. World Dev. 2005, 33, 1473-1490. [CrossRef]

82. Quaedvlieg, J.; García Roca, I.M.; Ros-Tonen, M.A.F. Is Amazon nut certification a solution for increased smallholder empowerment in Peruvian Amazonia? J. Rural Stud. 2014, 33, 41-55. [CrossRef]

83. Caspa, R.G.; Tchouamo, I.R.; Mweru, J.-P.M.; Mbang, J.A. Marketing Ricinodendron heudelotii Kernels and Gnetum spp. Leaves Around Lobeke National Park, East Cameroon. Tropicultura 2018, 36, 565-577.

84. Cosyns, H.; Degrande, A.; Wulf, R.; de van Damme, P.; Tchoundjeu, Z. Can commercialization of NTFPs alleviate poverty? A case study of Ricinodendron heudelotii (Baill.) Pierre ex Pax. kernel marketing in Cameroon. J. Agric. Rural Dev. Trop. Subtrop. 2011, 112, 45-56.

85. Foundjem Tita, D.; D’Haese, M.; Degrande, A.; Tchoundjeu, Z.; van Damme, P. Farmers' satisfaction with group market arrangements as a measure of group market performance: A transaction cost analysis of Non Timber Forest Products' producer groups in Cameroon. For. Policy Econ. 2011, 13, 545-553. [CrossRef]

86. Ndumbe, L.N.; Ingram, V.; Tchamba, M.; Nya, S. From trees to money: The contribution of njansang (Ricinodendron heudelotii) products to value chain stakeholders' financial assets in the South West Region of Cameroon. For. Trees Livelihoods 2018, 1-16. [CrossRef]

87. Jasaw, G.S.; Saito, O.; Takeuchi, K. Shea (Vitellaria paradoxa) Butter Production and Resource Use by Urban and Rural Processors in Northern Ghana. Sustainability 2015, 7, 3592-3614. [CrossRef]

88. Kombiok, E.; Agbenyega, O. The characteristics of financing arrangements for the production and marketing of shea (Vitellaria paradoxa) butter in Tamale in the Northern Region of Ghana. South. For. 2017, 79, 153-160. [CrossRef]

89. Pouliot, M. Contribution of "Women's Gold" to West African Livelihoods: The Case of Shea (Vitellaria paradoxa) in Burkina Faso. Econ. Bot. 2012, 66, 237-248. [CrossRef]

90. Shackleton, S.; Shackleton, C. The contribution of marula (Sclerocarya Birrea) fruit and fruit products to rural livelihoods in the Bushbuckridge district, South Africa: Balancing domestic needs and commercialisation. For. Trees Livelihoods 2005, 15, 3-24. [CrossRef]

91. Shackleton, S.; Campbell, B.; Lotz-Sisitka, H.; Shackleton, C. Links between the Local Trade in Natural Products, Livelihoods and Poverty Alleviation in a Semi-arid Region of South Africa. World Dev. 2008, 36, 505-526. [CrossRef]

92. Wynberg, R.; Cribbins, J.; Leakey, R.; Lombard, C.; Mander, M.; Shackleton, S.; Sullivan, C. Knowledge on Sclerocarya birrea subsp. caffra with emphasis on its importance as a non-timber forest product in South and southern Africa: A summary: Part 2: Commercial use, tenure and policy, domestication, intellectual property rights and benefit-sharing. S. Afr. For. J. 2002, 67-77.

93. Egelyng, H.; Bosselmann, A.S.; Warui, M.; Maina, F.; Mburu, J.; Gyau, A. Origin products from African forests: A Kenyan pathway to prosperity and green inclusive growth? For. Policy Econ. 2017, 84, 38-46. [CrossRef]

94. Girma, J.; Gardebroek, C. The impact of contracts on organic honey producers' incomes in southwestern Ethiopia. For. Policy Econ. 2015, 50, 259-268. [CrossRef]

95. Ingram, V. Savannah Forest Beekeepers in Cameroon: Actions to Reduce Vulnerability. In Dryland Forests: Management and Social Diversity in Africa and Asia; Bose, P., van Dijk, H., Eds.; Springer International Publishing: Cham, Switzerland, 2016; pp. 139-163.

96. Lowore, J.; Meaton, J.; Wood, A. African Forest Honey: An Overlooked NTFP with Potential to Support Livelihoods and Forests. Environ. Manag. 2018, 62, 15-28. [CrossRef] 
97. Matias, D.M.S.; Tambo, J.A.; Stellmacher, T.; Borgemeister, C.; von Wehrden, H. Commercializing traditional non-timber forest products: An integrated value chain analysis of honey from giant honey bees in Palawan, Philippines. For. Policy Econ. 2018, 97, 223-231. [CrossRef]

98. Musinguzi, P.; Bosselmann, A.S.; Pouliot, M. Livelihoods-conservation initiatives: Evidence of socio-economic impacts from organic honey production in Mwingi, Eastern Kenya. For. Policy Econ. 2018, 97, 132-145. [CrossRef]

99. Dias Trevisan, A.C.; Fantini, A.C.; Schmitt-Filho, A.L.; Farley, J. Market for Amazonian Acai (Euterpe oleraceae) Stimulates Pulp Production from Atlantic Forest Jucara Berries (Euterpe edulis). Agroecol. Sustain. Food Syst. 2015, 39, 762-781. [CrossRef]

100. Sousa, F.F.; de Vieira-da-Silva, C.; Barros, F.B. The (in)visible market of miriti (Mauritia flexuosa L.f.) fruits, the "winter acai", in Amazonian riverine communities of Abaetetuba, Northern Brazil. Glob. Ecol. Conserv. 2018, 14, e00393. [CrossRef]

101. Cai, M.; Pettenella, D.; Vidale, E. Income generation from wild mushrooms in marginal rural areas. For. Policy Econ. 2011, 13, 221-226. [CrossRef]

102. Secco, L.; Pettenella, D.; Maso, D. 'Net-System' Models Versus Traditional Models in NWFP Marketing: The Case of Mushrooms. Small-Scale For. Econ. Manag Policy 2009, 8, 349-365. [CrossRef]

103. Ofundem, T.; Ndip, N.R.; Abdon, A.; Patrice, L. Bush mango (Irvingia spp.): Forest and on-farm resource availability and market chains in the Southwest Region of Cameroon. For. Trees Livelihoods 2017, 26, 170-182. [CrossRef]

104. Krause, T.; Ness, B. Energizing agroforestry: Ilex guayusa as an additional commodity to diversify Amazonian agroforestry systems. Int. J. Biodivers. Sci. Ecosyst. Serv. Manag. 2017, 13, 191-203. [CrossRef]

105. Ludvig, A.; Tahvanainen, V.; Dickson, A.; Evard, C.; Kurttila, M.; Cosovic, M.; Chapman, E.; Wilding, M.; Weiss, G. The practice of entrepreneurship in the non-wood forest products sector: Support for innovation on private forest land. For. Policy Econ. 2016, 66, 31-37. [CrossRef]

106. Zivojonovic, I.; Nedeljkovic, J.; Stojanovski, V.; Japelj, A.; Nonic, D.; Weiss, G.; Ludvig, A. Non-timber forest products in transition economies: Innovation cases in selected SEE countries. For. Policy Econ. 2017, 81, 18-29. [CrossRef]

107. Delgado-Lemus, A.; Casas, A.; Téllez, O. Distribution, abundance and traditional management of Agave potatorumin the Tehuacán Valley, Mexico: Bases for sustainable use of non-timber forest products. J. Ethnobiol. Ethnomed. 2014, 10, 63. [CrossRef]

108. Lebbie, A.R.; Guries, R.P. The palm wine trade in Freetown, Sierra Leone: Production, income, and social construction. Econ. Bot. 2002, 56, 246-254. [CrossRef]

109. Martins, A.R.O.; Shackleton, C.M. The production and commercialization of palm wine from Hyphaene coriacea and Phoenix reclinata in Zitundo area, southern Mozambique. S. Afr. J. Bot. 2018, 116, 6-15. [CrossRef]

110. Hogarth, N.J.; Belcher, B. The contribution of bamboo to household income and rural livelihoods in a poor and mountainous county in Guangxi, China. Int. For. Rev. 2013, 15, 71-81. [CrossRef]

111. Keca, L.J.; Keca, N.; Rekola, M. Value chains of Serbian non-wood forest products. Int. For. Rev. 2013, 15, 315-335.

112. Keca, L.; Marceta, M. Export as Market Component and Development Perspective of NWFPs Sector in Central Serbia. Balt. For. 2015, 21, 315-325.

113. Mala, W.A.; Tieguhong, J.C.; Ndoye, O.; Grouwels, S.; Betti, J.L. Collective action and promotion of forest based associations on non-wood forest products in Cameroon. Dev. Pract. 2012, 22, 1122-1134. [CrossRef]

114. Adam, Y.O.; Shackleton, C.M. Distribution and use of cash income from basket and mat crafting: Implications for rural livelihoods in the Eastern Cape, South Africa. For. Trees Livelihoods 2016, 25, 199-211. [CrossRef]

115. Ahmed, R.; Islam, A.N.M.F.; Rahman, M.; Halim, M.A. Management and economic value of Schumannianthus dichotoma in rural homesteads in the Sylhet region of Bangladesh. Int. J. Biodivers. Sci. Manag. 2007, 3, 252-258. [CrossRef]

116. Coomes, O.T. Rain forest 'conservation-through-use'? Chambira palm fibre extraction and handicraft production in a land-constrained community, Peruvian Amazon. Biodivers. Conserv. 2004, 13, 351-360. [CrossRef]

117. Dovie, D.B.K. Rural economy and livelihoods from the non-timber forest products trade. Compromising sustainability in southern Africa? Int. J. Sustain. Dev. World Ecol. 2003, 10, 247-262. [CrossRef] 
118. Greene, S.M.; Hammett, A.L.; Kant, S. Non-Timber Forest Products Marketing Systems and Market Players in Southwest Virginia. J. Sustain. For. 2000, 11, 19-39. [CrossRef]

119. Godoy, R.A.; Feaw, T.C. The profitability of smallholder rattan cultivation in Southern Borneo, Indonesia. Hum. Ecol. 1989, 17, 347-363. [CrossRef]

120. Guadagnin, D.L.; Gravato, I.C. Ethnobotany, Availability, and Use of Lianas by the Kaingang People in Suburban Forests in Southern Brazil. Econ. Bot. 2013, 67, 350-362. [CrossRef]

121. Lincoln, K.; Orr, B. The Use and Cultural Significance of the Pita Plant (Aechmea magdalenae) among Ngöbe Women of Chalite, Panama. Econ. Bot. 2011, 65, 13-26. [CrossRef]

122. Mukul, S.A.; Rana, P. The trade of bamboo (Graminae) and its secondary products in a regional market of southern Bangladesh: Status and socio-economic significance. Int. J. Biodivers. Sci. Ecosyst. Ser. Manag. 2013, 9, 146-154. [CrossRef]

123. Pereira, T.; Shackleton, C.; Shackleton, S. Trade in reed-based craft products in rural villages in the Eastern Cape, South Africa. Dev. S. Afr. 2006, 23, 477-495. [CrossRef]

124. Rahman, M.H.; Fardusi, M.J.; Roy, B.; Kamal, M.M.; Uddin, M.J.; Khan, M.A.S.A. Production, Economics, Employment Generation and Marketing Pattern of Rattan-Based Cottage Enterprises: A Case Study from an Urban Area of North-Eastern Bangladesh. Small-Scale For. 2012, 11, 207-221. [CrossRef]

125. Rana, M.P.; Mukul, S.A.; Sohel, M.S.I.; Chowdhury, M.S.H.; Akhter, S.; Chowdhury, M.Q.; Koike, M. Economics and Employment Generation of Bamboo-Based Enterprises: A Case Study from Eastern Bangladesh. Small-Scale For. 2010, 9, 41-51. [CrossRef]

126. Runk, J.V. Wounaan and Emberá use and management of the fiber palm Astrocaryum standleyanum (Arecaceae) for basketry in eastern Panamá. Econ. Bot. 2001, 55, 72-82. [CrossRef]

127. Vormisto, J. Making and Marketing Chambira Hammocks and Bags in the Village of Brillo Nuevo, Northeastern Peru. Econ. Bot. 2002, 56, 27-40. [CrossRef]

128. Gyan, C.A.; Shackleton, C.M. Abundance and commercialization of Phoenix reclinata in the King Williamstown area, South Africa. J. Trop. For. Sci. 2005, 17, 334-345.

129. Mjoli, N.; Shackleton, C.M. The Trade in and Household Use of Phoenix reclinata Palm Frond Hand Brushes on the Wild Coast, South Africa. Econ. Bot. 2015, 69, 218-229. [CrossRef]

130. Rico García-Amado, L.; Ruiz Pérez, M.; Dahringer, G.; Reyes Escutia, F.; Barrasa García, S.; Contreras Mejía, E. From wild harvesting to agroforest cultivation: A Chamaedorea palm case study from Chiapas, Mexico. For. Policy Econ. 2013, 28, 44-51. [CrossRef]

131. Shackleton, S.E.; Campbell, B.M. The traditional broom trade in Bushbuckridge, South Africa: Helping poor women cope with adversity. Econ. Bot. 2007, 61, 256-268. [CrossRef]

132. Forero-Montaña, J.; Zimmerman, J.K.; Santiago, L.E. Analysis of the potential of small-scale enterprises of artisans and sawyers as instruments for sustainable forest management in Puerto Rico. J. Sustain. For. 2018, 37, 257-269. [CrossRef]

133. Koenig, J.; Altman, J.; Griffiths, A.D. Indigenous Livelihoods and Art Income: Participation, production and returns from woodcarvings in Arnhem Land, north Australia. Aust. Geogr. 2011, 42, 351-369. [CrossRef]

134. López-Serrano, Y.; Pineda-López, M.d.R.; Sánchez-Velásquez, L.R. Is the Use of a Non-timber Forest Resource Compatible with Environmental Conservation? The Case of Handicraft Production at the Cofre de Perote National Park, Mexico. Small-Scale For. Econ. Manag. Policy 2018, 17, 57-69. [CrossRef]

135. Virapongse, A.; Schmink, M.; Larkin, S. Value chain dynamics of an emerging palm fiber handicraft market in Maranhão, Brazil. For. Trees Livelihoods 2014, 23, 36-53. [CrossRef]

136. Ainembabazi, J.H.; Shively, G.; Angelsen, A. Charcoal production and household welfare in Uganda: A quantile regression approach. Environ. Dev. Econ. 2013, 18, 537-558. [CrossRef]

137. Bennett-Curry, A.; Malhi, Y.; Menton, M. Leakage effects in natural resource supply chains: A case study from the Peruvian commercial charcoal market. Int. J. Sustain. Dev. World Ecol. 2013, 20, 336-348. [CrossRef]

138. Brobbey, L.K.; Hansen, C.P.; Kyereh, B.; Pouliot, M. The economic importance of charcoal to rural livelihoods: Evidence from a key charcoal-producing area in Ghana. For. Policy Econ. 2019, 101, 19-31. [CrossRef]

139. Coomes, O.T.; Burt, G.J. Peasant charcoal production in the Peruvian Amazon: Rainforest use and economic reliance. For. Ecol. Manag. 2001, 140, 39-50. [CrossRef]

140. Schure, J.; Levang, P.; Wiersum, K.F. Producing Woodfuel for Urban Centers in the Democratic Republic of Congo: A Path Out of Poverty for Rural Households? World Dev. 2014, 64, 80-90. [CrossRef] 
141. Smith, H.E.; Hudson, M.D.; Schreckenberg, K. Livelihood diversification: The role of charcoal production in southern Malawi. Energy Sustain. Dev. 2017, 36, 22-36. [CrossRef]

142. Smith, H.E.; Jones, D.; Vollmer, F.; Baumert, S.; Ryan, C.M.; Woollen, E.; Lisboa, S.N.; Carvalho, M.; Fisher, J.A.; Luz, A.C.; et al. Urban energy transitions and rural income generation: Sustainable opportunities for rural development through charcoal production. World Dev. 2019, 113, 237-245. [CrossRef]

143. Abtew, A.A.; Pretzsch, J.; El-Sheikh Mohmoud, T.; Adam, Y.O. Commodity Chain of Frankincense from the Dry Woodlands of Nuba Mountains, South Kordofan State, Sudan. Small-Scale For. Econ. Manag. Policy 2012, 11, 365-388. [CrossRef]

144. Gebru, Y.; Ewnetu, Z.; Kassa, H.; Padoch, C. Determinants of producers' participation in gums and resins value chains from dry forests and analysis of marketing channels in northwestern and southern Ethiopia. For. Trees Livelihoods 2014, 23, 54-66. [CrossRef]

145. Lacuna-Richman, C. Using suitable projects in adding value to non-wood forest products in the Philippines: The copal (Agathis philippinensis) trade in Palawan. Econ. Bot. 2004, 58, 476-485. [CrossRef]

146. Mahdavi, A. The economic, social, and ecological impacts of wild pistachio (Pistacia atlantica Desf.) oleo-gum resin extraction cooperatives in Zagros forests, Ilam province, Iran. For. Trees Livelihoods 2015, 24, $275-284$. [CrossRef]

147. Mujawamariya, G.; D'Haese, M. In search for incentives to gum arabic collection and marketing in Senegal: Interlocking gum trade with pre-finances from traders. For. Policy Econ. 2012, 25, 72-82. [CrossRef]

148. Tilahun, M.; Maertens, M.; Deckers, J.; Muys, B.; Mathijs, E. Impact of membership in frankincense cooperative firms on rural income and poverty in Tigray, Northern Ethiopia. For. Policy Econ. 2016, 62, 95-108. [CrossRef]

149. Widianingsih, N.N.; Schmidt, L.H.; Theilade, I. Jernang (Daemonorops spp.) commercialization and its role for rural incomes and livelihoods in Southern Sumatra, Indonesia. For. Trees Livelihoods 2019, 28, 1-17. [CrossRef]

150. Galloway, F.B.; Wynberg, R.P.; Nott, K. Commercialising a perfume plant, Commiphora wildii: Livelihood implications for indigenous Himba in north-west Namibia. Int. For. Rev. 2016, 18, 429-443. [CrossRef]

151. Gauli, K.; Hauser, M. Commercial management of non-timber forest products in Nepal's community forest users groups: Who benefits? Int. For. Rev. 2011, 13, 35-45.

152. Rahman, M.; Nath, N.M.; Sarker, S.; Adnan, M.; Islam, M. Management and Economic Aspects of Growing Aquilaria agallocha Roxb. in Bangladesh. Small-Scale For. Econ. Manag. Policy 2015, 14, 459-478. [CrossRef]

153. Rasul, G.; Choudhary, D.; Pandit, B.H.; Kollmair, M. Poverty and Livelihood Impacts of a Medicinal and Aromatic Plants Project in India and Nepal: An Assessment. Mt. Res. Dev. 2012, 32, 137-148. [CrossRef]

154. Uddin, M.S.; Mukul, S.A.; Khan, M.A.S.A.; Alamgir, M.; Harun, M.Y.; Alam, M.S. Small-scale Agar (Aquilaria agallocha Roxb.) Based Cottage Enterprises in Maulvibazar District of Bangladesh: Production, Marketing and Potential Contribution to Rural Development. Small-Scale For. Econ. Manag. Policy 2008, 7, 139-149. [CrossRef]

155. Ajonina, P.U.; Ajonina, G.N.; Jin, E.; Mekongo, F.; Ayissi, I.; Usongo, L. Gender roles and economics of exploitation, processing and marketing of bivalves and impacts on forest resources in the Sanaga Delta region of Douala-Edea Wildlife Reserve, Cameroon. Int. J. Sustain. Dev. World Ecol. 2005, 12, 161-172. [CrossRef]

156. Da Silva, R.R.V.; Gomes, L.J.; Albuquerque, U.P. What are the socioeconomic implications of the value chain of biodiversity products? A case study in Northeastern Brazil. Environ. Monit. Assess. 2017, 189, 64. [CrossRef]

157. Panda, P.K. Inclusion and economic empowerment of rural-tribal women in lac value chain and market: A case study of Udyogini. J. Soc. Econ. Dev. 2017, 19, 25-41. [CrossRef]

158. Avocèvou-Ayisso, C.; Sinsin, B.; Adégbidi, A.; Dossou, G.; van Damme, P. Sustainable use of non-timber forest products: Impact of fruit harvesting on Pentadesma butyracea regeneration and financial analysis of its products trade in Benin. For. Ecol. Manag. 2009, 257, 1930-1938. [CrossRef]

159. Le Polain de Waroux, Y.; Lambin, E.F. Niche Commodities and Rural Poverty Alleviation: Contextualizing the Contribution of Argan Oil to Rural Livelihoods in Morocco. Ann. Assoc. Am. Geogr. 2013, 103, 589-607. [CrossRef]

160. Lybbert, T.J.; Barrett, C.B.; Narjisse, H. Market-based conservation and local benefits: The case of argan oil in Morocco. Ecol. Econ. 2002, 41, 125-144. [CrossRef] 
161. Buchmann, C.; Prehsler, S.; Hartl, A.; Vogl, C.R. The Importance of Baobab (Adansonia digitata L.) in Rural West African Subsistence-Suggestion of a Cautionary Approach to International Market Export of Baobab Fruits. Ecol. Food Nutr. 2010, 49, 145-172. [CrossRef]

162. Williams, S.J.; Jones, J.P.G.; Annewandter, R.; Gibbons, J.M. Cultivation can increase harvesting pressure on overexploited plant populations. Ecol. Appl. 2014, 24, 2050-2062. [CrossRef]

163. Leakey, R.R.B.; Tchoundjeu, Z.; Schreckenberg, K.; Shackleton, S.E.; Shackleton, C.M. Agroforestry Tree Products (AFTPs): Targeting Poverty Reduction and Enhanced Livelihoods. Int. J. Agric. Sustain. 2005, 3, 1-23. [CrossRef]

164. Schreckenberg, K.; Awono, A.; Degrande, A.; MBOSSO, C.; Ndoye, O.; Tchoundjeu, Z. Domesticating indigenous fruit trees as a contribution to poverty reduction. For. Trees Livelihoods 2006, 16, 35-51. [CrossRef]

165. Hermann, M. The impact of the European Novel Food Regulation on trade and food innovation based on traditional plant foods from developing countries. Food Policy 2009, 34, 499-507. [CrossRef]

166. Liu, S.; Xu, J. Livelihood mushroomed: Examining household level impacts of non-timber forest products (NTFPs) under new management regime in China's state forests. For. Policy Econ. 2019, 98, 44-53. [CrossRef]

167. Sathre, R.; Gustavsson, L. Process-based analysis of added value in forest product industries. For. Policy Econ. 2009, 11, 65-75. [CrossRef]

168. te Velde, D.W.; Rushton, J.; Schreckenberg, K.; Marshall, E.; Edouard, F.; Newton, A.; Arancibia, E. Entrepreneurship in value chains of non-timber forest products. For. Policy Econ. 2006, 8, 725-741. [CrossRef]

169. Tieguhong, J.C.; Grouwels, S.; Ndoye, O.; Mala, A.W.; Fokou Sakam, I.; Useni, M.; Betti, J.L. Financial status of small and medium scale enterprises based on non-wood forest products (NWFP) in Central Africa. For. Policy Econ. 2012, 20, 112-119. [CrossRef]

170. Chagwiza, C.; Muradian, R.; Ruben, R.; Tessema, W. Collective Entrepreneurship and Rural Development: Comparing Two Types of Producers' Organizations in the Ethiopian Honey Sector. In Network Governance: Alliances, Cooperatives and Franchise Chains; Ehrmann, T., Windsperger, J., Cliquet, G., Hendrikse, G., Eds.; Springer: Berlin/Heidelberg, Germany, 2013; pp. 149-169.

171. Pandit, B.H.; Albano, A.; Kumar, C. Community-Based Forest Enterprises in Nepal: An Analysis of Their Role in Increasing Income Benefits to the Poor. Small-Scale For. 2009, 8, 447-462. [CrossRef]

172. Kilchling, P.; Hansmann, R.; Seeland, K. Demand for non-timber forest products: Surveys of urban consumers and sellers in Switzerland. For. Policy Econ. 2009, 11, 294-300. [CrossRef]

173. Seeland, K.; Kilchling, P.; Hansmann, R. Urban Consumers' Attitudes Towards Non-wood Forest Products and Services in Switzerland and an Assessment of Their Market Potential. Small-Scale For. Econ. Manag. Policy 2007, 6, 443-452. [CrossRef]

174. Wiersum, K.F.; Ingram, V.J.; Ros-Tonen, M.A.F. Governing access to resources and markets in non-timber forest product chains. For. Trees Livelihoods 2014, 23, 6-18. [CrossRef]

175. Tomaselli, M.F.; Timko, J.; Kozak, R. The Role of Government in the Development of Small and Medium Forest Enterprises: Case Studies from The Gambia. Small-Scale For. Econ. Manag. Policy 2012, 11, 237-253. [CrossRef]

176. Tieguhong, J.C.; Ingram, V.; Mala, W.A.; Ndoye, O.; Grouwels, S. How governance impacts non-timber forest product value chains in Cameroon. For. Policy Econ. 2015, 61, 1-10. [CrossRef]

177. Weiss, G.; Ludvig, A.; Zivojinovic, I.; Asamer-Handler, M.; Huber, P. Non-timber innovations: How to innovate in side-activities of forestry Case study Styria, Austria. Austrian J. For. Sci. 2017, 134, 231-250.

178. Mechik, E.; von Hauff, M.; Moura, L.H.L.; de Held, H. Analysis of the changes in economic activities of Brazilian forest communities after methodical support and provision of pre-financing capital. J. Trop. For. Sci. 2017, 29, 227-237.

179. Ros-Tonen, M.A.F.; Kusters, K. Pro-poor Governance of Non-timber Forest Products: The Need for Secure Tenure, the Rule of Law, Market Access and Partnerships. In Non-Timber Forest Products in the Global Context; Shackleton, S., Shackleton, C., Shanley, P., Eds.; Springer: Berlin/Heidelberg, Germany, 2011.

180. Bowler, D.E.; Buyung-Ali, L.M.; Healey, J.R.; Jones, J.P.G.; Knight, T.M.; Pullin, A.S. Does community forest management provide global environmental benefits and improve local welfare? Front. Ecol. Environ. 2012, 10, 29-36. [CrossRef]

181. Gram, S. Economic valuation of special forest products: An assessment of methodological shortcomings. Ecol. Econ. 2001, 36, 109-117. [CrossRef] 
182. Marshall, E.; Newton, A.C.; Schreckenberg, K. Commercialisation of non-timber forest products: First steps in analysing the factors influencing success. Int. For. Rev. 2003, 5, 128-137. [CrossRef]

183. Cunningham, A.B.; Ingram, W.; Kadati, W.; Maduarta, I.M. Opportunities, barriers and support needs: Micro-enterprise and small enterprise development based on non-timber products in eastern Indonesia. Aust. For. 2017, 80, 161-177. [CrossRef]

184. Badini, O.S.; Hajjar, R.; Kozak, R. Critical success factors for small and medium forest enterprises: A review. For. Policy Econ. 2018, 94, 35-45. [CrossRef]

185. Macqueen, D.; Bolin, A.; Greijmans, M.; Grouwels, S.; Humphries, S. Innovations towards prosperity emerging in locally controlled forest business models and prospects for scaling up. World Dev. 2018, in press. [CrossRef]

186. Pettenella, D.; Secco, L.; Maso, D. NWFP\&S Marketing: Lessons Learned and New Development Paths from Case Studies in Some European Countries. Small-Scale For. Econ. Manag. Policy 2007, 6, 373-390. [CrossRef]

187. Shackleton, C.M.; Pandey, A.K. Positioning non-timber forest products on the development agenda. For. Policy Econ. 2014, 38, 1-7. [CrossRef]

188. Belcher, B.M. Forest product markets, forests and poverty reduction. Int. For. Rev. 2005, 7, 82-89. [CrossRef]

189. Pullanikkatil, D.; Shackleton, C.M. Listening to the Stories. In Poverty Reduction Through Non-Timber Forest Products: Personal Stories; Pullanikkatil, D., Shackleton, C.M., Eds.; Springer International Publishing: Cham, Switzerland, 2019; pp. 153-160.

(C) 2019 by the authors. Licensee MDPI, Basel, Switzerland. This article is an open access article distributed under the terms and conditions of the Creative Commons Attribution (CC BY) license (http://creativecommons.org/licenses/by/4.0/). 